\title{
Revision of Chone Krøyer, 1856 (Polychaeta: Sabellidae) from the eastern central Atlantic and Mediterranean Sea with descriptions of two new species
}

\author{
MARÍA ANA TOVAR-HERNÁNDEZ ${ }^{1}$, MARGHERITA LICCIANO ${ }^{2}$ \\ and ADRIANA GIANGRANDE ${ }^{2}$

\footnotetext{
${ }^{1}$ Laboratorio de Poliquetos, El Colegio de la Frontera Sur, Unidad Chetumal, Avenida Centenario Km 5.5, 77900, Chetumal, Quintana Roo, Mexico. E-mail: maria_ana_tovar@yahoo.com
} \\ ${ }^{2}$ Dipartimento di Scienze e Tecnologie Biologiche ed Ambientali, via Prov. Lecce-Monteroni, 73100, Lecce, Italy,
}

\begin{abstract}
SUMMARY: A neotype specimen is designated for Chone acustica (Claparède, 1870) with a full description. The original descriptions of Chone arenicola Langerhans, 1880 and Chone collaris Langerhans, 1880, both from Madeira, did not include some details and incomplete or misleading information was provided, so both species are redescribed. Amendments to the description of Chone longiseta Giangrande, 1992 are also given together with the methyl green staining pattern of Chone usticensis Giangrande et al. 2006. Two new species are described: Chone gambiae sp. nov., from the Gulf of Naples and Chone dunerificta sp. nov., from the Gulf of Salerno. This study shows the distribution of Chone duneri Krøyer, 1856, and Chone filicaudata Southern, 1914, to be restricted to the Arctic seas and North Atlantic Ocean, respectively. Records from the Mediterranean Sea are found to be erroneous.
\end{abstract}

Keywords: Sabellidae, Chone duneri, Chone filicaudata, Chone dunerificta, Chone gambiae.

RESUMEN: Especies de Chone Krøyer, 1856 (Polychaeta: Sabellidae) del Atlántico Oriental central y Mar MEDITERRÁNEO. - Se designó el neotipo de Chone acustica (Claparède, 1870). Las descripciones originales de Chone arenicola Langerhans, 1880 y Chone collaris Langerhans, 1880, ambas de Madeira, no incluyen carácteres diagnósticos y la información proporcionada en otras contribuciones es incompleta, en este estudio ambas especies fueron redescritas. Se adicionaron carácteres diagnósticos a la descripción de Chone longiseta Giangrande, 1992, y se describió el patrón de tinción con verde de metilo de Chone usticensis Giangrande et al. 2006. Se describieron dos nuevas especies: Chone gambiae sp. nov., del Golfo de Nápoles y Chone dunerificta sp. nov., del Golfo de Salerno. Se restringió la distribución de Chone duneri Krøyer, 1856 para los mares del Ártico y Chone filicaudata Southern, 1914 para el Océano Atlántico Norte. Los registros de ambas especies para el Mar Mediterráneo son erróneos.

Palabras clave: Sabellidae, Chone duneri, Chone filicaudata, Chone dunerificta, Chone gambiae.

\section{INTRODUCTION}

Chone Krøyer, 1856, is a genus of sabellid polychaetes frequently found in soft-bottom marine sediments. Banse (1972) commented on the definitional problems with the genus, noting that Krøyer's (1856) original intent in erecting the genus was to indicate the distinct nature of the palmate membrane. Fitzhugh (1989) stated that some specimens, identified as Chone infundibuliformis, have dorsal lips with dorsal radiolar appendages (elongate and distally tapered), whereas other specimens lack them (low and broadly rounded); he named them as Chone1 and Chone2, respectively. In his cladistic 
analysis, Chone2 was basal to Chone1 and Euchone, which share dorsal radiolar appendages. This suggest that if the radiolar appendages have been lost in certain species of Chone, this character might be used to define the genus; however, exclusive of the apparent loss of the dorsal radiolar appendages in some species, Chone as a group is not defined by any apomorphy, but rather it is a combination of characters and their absences that characterises the group. Thus, a phylogenetic analysis is strong enough to reveal in detail the groupings between the taxa currently referred to Chone.

In this scenario, as part of an ongoing worldwide revision of the genus, species of Chone from the Grand Caribbean were studied recently by TovarHernández (2005); the redescription of the type species (Chone infundibuliformis Krøyer, 1856) was proportioned by Tovar-Hernández and SosaRodríguez (2006); and the revision of species of Chone from North America was made by TovarHernández (in press).

In this study we reviewed species of Chone previously recorded for the Mediterranean Sea: $C$. arenicola Langerhans, 1880 and C. collaris Langerhans, 1880 (described from Madeira); $C$. acustica (Claparède, 1870); C. longiseta Giangrande, 1992 and C. usticensis Giangrande et al., 2006 (Italian coasts); C. duneri Malmgren, 1867 (Norway); and C. filicaudata Southern, 1914 (Ireland). With the exception of $C$. usticensis, which is a recent record, all the species have been frequently recorded for ecological and monitoring studies in the Mediterranean Sea (Vatova, 1949; Rullier and Amoreaux, 1968; Katzman, 1973; Cognetti Varriale and Zunarelli Vandini, 1978; Drago and Albertelli, 1978; Albertelli et al. 1981; Castelli, 1982; Katzman, 1982; Albertelli et al. 1983; Farina et al. 1985; Bedulli et al. 1986; Giangrande, 1989). Although Chone has already been the subject of extensive study in the Mediterranean area (Giangrande, 1992), there still are several gaps in our understanding of the taxon. This is particularly the case in Mediterranean waters, because many of the relevant original descriptions and illustrations lack sufficient detail. Also, general faunal studies rarely verify identifications against type material or the original drawings, causing many erroneous records to appear in the literature.

The present study of type and non-type materials of species described or recorded from the eastern central Atlantic and Mediterranean Sea redescribes the previously known species, describes two new species, and recognises a distribution for $C$. duneri and $C$. filicaudata of the Arctic seas and the North Atlantic Ocean, respectively.

\section{METHODS}

Type and non-type material was examined from the following collections: the Natural History Museum, London (BMNH); Departamento de Zoología, Universidad de La Laguna, Tenerife (DZUL); Colección de Referencia, El Colegio de la Frontera Sur, Chetumal (ECOSUR); Florida Marine Research Institute (FSBC); Los Angeles County Museum of Natural History, Allan Hancock Foundation (LACM-AHF); Laboratorio di Ecologia del Benthos, Stazione Zoologica "Anton Dohrn", Ischia, Naples (LEB); Museum of Comparative Zoology, Harvard University (MCZ); Naturhistorisches Museum Wien (NHMW); National Museum of Wales (NMW); Private Collection, Laboratorio di Zoologia, Università degli Studi di Lecce, Italy (PC-ZL); Swedish Museum of Natural History, Stockholm (SMNH); National Museum of Natural History, Smithsonian Institution, Washington (USNM); Yale Peabody Museum, New Haven (YPM); Zoological Museum of the University of Copenhagen (ZMUC). Type material from the new taxa described here were deposited at the Museo Nacional de Ciencias Naturales de Madrid (MNCN).

In order to standardise and facilitate comparison between species of Chone and for further phylogenetic studies, this study follows the terminology and measures proposed by Tovar-Hernández (2005) and Tovar-Hernández and Sosa-Rodríguez (2006). For the relative extension of radiolar tips and mucro of paleate chaetae, the following classification is used:

Radiolar tips: a) Short (S) if the distal pinnules almost reach the radiolar tips (Figs 1A-B); b) medium-sized (M) if their length is $1 / 8$ of the branchial crown length (Fig. 1C); c) long (L) if their length is one quarter of the branchial crown length (Figs 1D$\mathrm{E})$; and d) extra long (XL) if they are as long as half (or more) of the branchial crown length (Fig. 1F).

Mucro: a) Minute (m) if it is tiny, hair-like, or indiscernible; b) short (S), if the mucro is equal to or shorter than a quarter of the paleal width; c) medium (M), if it is as long as half the paleal width (Fig. 2A); 

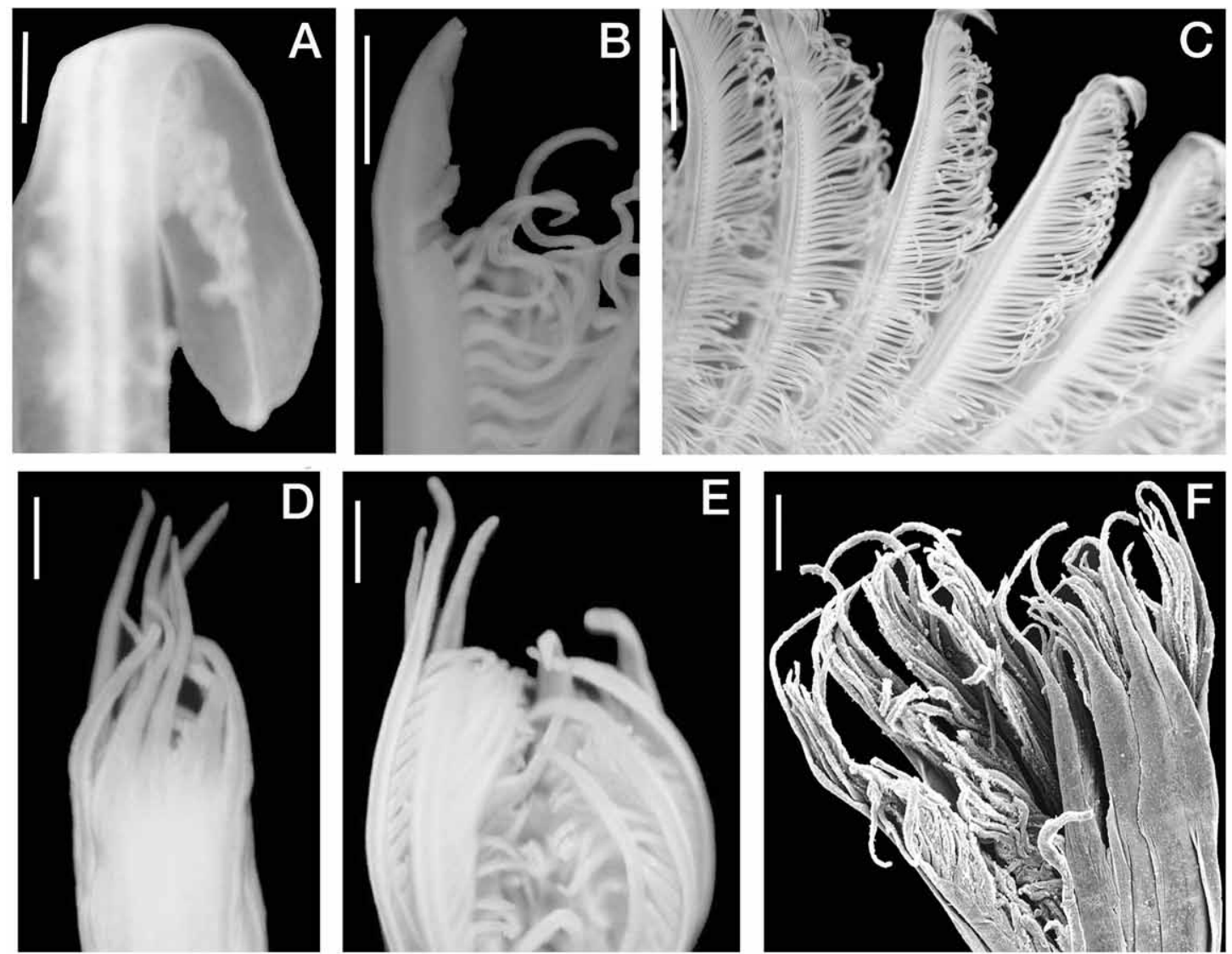

FIG. 1. - Length of radiolar tips. A-B, short; C, medium; D-E, long; F, extra long. Scale bars: A-C, $0.5 \mathrm{~mm}$; D-E, 1 mm; F, 2 mm
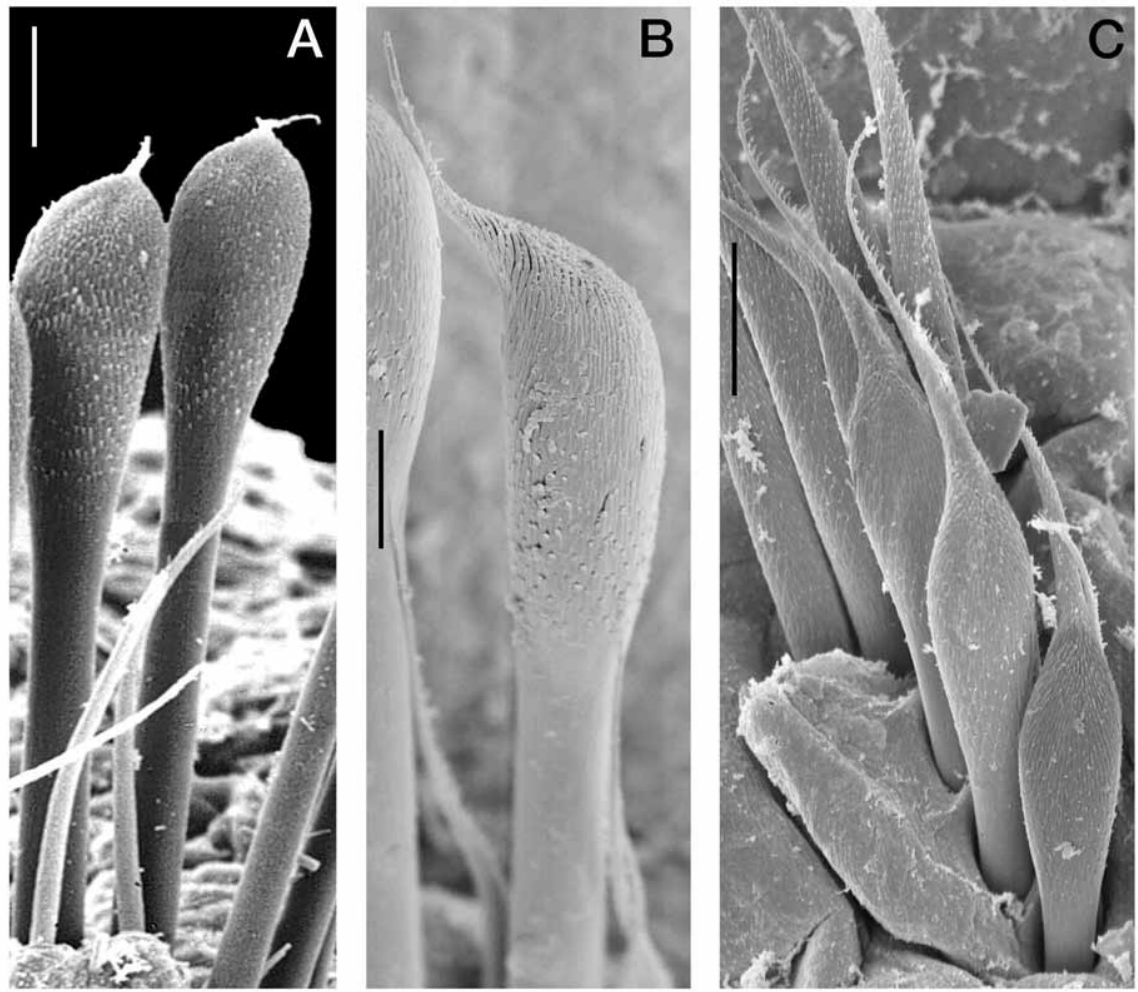

FIG. 2. - Length of mucro. A, medium; B, long; C, extra long. Scale bars: A-B, $10 \mu \mathrm{m} ; \mathrm{C}, 5 \mu \mathrm{m}$. 
d) long (L), if the mucro is as long (or twice as long) as the paleal width (Fig. 2B); and e) extra long (XL) if it is three or more times longer than the paleal width (Fig. 2C).

Unless otherwise stated, every description is based on the available type material and any variation found in additional types is included in parentheses. In all species of Chone, the biannulate condition in thoracic segments is given by the presence of distinct intra-notopodial and intra-neuropodial grooves, less differentiated than inter-segmental grooves; when treated with methyl green all these grooves, the faecal groove and the noto- and neuropodial lips or lobes are not coloured. This pattern is omitted in descriptions.

\section{SYSTEMATICS}

Family SABELLIDAE Latreille, 1825

Subfamily SABELLinAE Latreille, 1825

Genus Chone Krøyer, 1856

Chone acustica (Claparède, 1870)

\section{(Fig. 3)}

Dialychone acustica Claparède, 1870: 169-171, Pl. 30, Fig. 3 [Gulf of Naples]. Lo Bianco, 1893: 77.

Chone acustica Knight-Jones et al. 1991: 849. Giangrande, 1992: 521-523, Figs 8-9.

Material examined

Type material: Neotype $[\mathrm{MNCN}]$, Paratype $[\mathrm{MNCN}]$ Gulf of Naples, Napoli Castel dell'Ovo, 40 $49.43^{\prime} \mathrm{N}, 14^{\circ} 14.35^{\prime} \mathrm{E}$, August 2004, $-8 \mathrm{~m}$.

Non-type material: Gulf of Naples [LEB] Portici, $40^{\circ} 49^{\prime} \mathrm{N}$, 14²19.28'E, 2002, -9 m (1); Portici, 4049'N, 14¹9.28'E, 2003, -9 m (2); Napoli, Castel dell'Ovo, $40^{\circ} 49.43$ 'N $14^{\circ} 14.35^{\prime} \mathrm{E}$, November 2004, -8 m (1). Tyrrhenian Sea [PC-ZL] 121 Gulf of Salerno, 1982, -20 m (6); 120 Foce di Tevere, 1980,-20 m (3); 155 Gulf of Policastro, 1983, -10 m (1); Ionian Sea [PC-ZL] 156 Puglia, 1980, $-10 \mathrm{~m}(2)$.

Additional material: Chone albocincta Banse, 1972, Paratypes [LACM-AHF POLY 0455]. Chone americana Day, 1973, Paratypes [USNM 43137]. Chone arenicola Langerhans, 1880, Syntype [NHMW 2286]. Chone aurantiaca (Johnson, 1901), Holotype [MCZ 1933]. Chone bimaculata Banse and Nichols, 1968, Paratypes [USNM 36280]. Chone collaris Langerhans, 1880, Syntype [NHMW 1966]. Chone diazi Tovar-Hernández, 2005, Paratype [ECOSUR 0051]. Chone duneri Malmgren, 1867, Topotypes [ZMUC POL-1755]. Chone ecaudata (Moore, 1923), Holotype [USNM 17319]. Chone farringtonae Tovar-Hernández, 2005, Paratype [ECOSUR 0052]. Chone gracilis Moore, 1906, Holotype [USNM 5513]. Chone infundibuliformis Krøyer, 1856, Lectotype [ZMUC POL-1749]. Chone johnstonae TovarHernández, 2005, Paratype [FSBC I 66737]. Chone letterstedti (Kinberg, 1867), Holotype [SMNH 576]. Chone longiseta Giangrande, 1992, Topotypes [PC-ZL]. Chone magna (Moore, 1923), Holotype [USNM 17281]. Chone mollis (Bush in Moore, 1904), Holotype [YPM 2793]. Chone perkinsi Tovar-Hernández, 2005, Paratype [ECOSUR 0053]. Chone picta (Verrill, 1885), Topotype [YPM 30002]. Chone uebelackerae Tovar-Hernández, 2005, Paratype [FSBC I 34709]. Chone usticensis Giangrande et al.
2006, Topotypes [PC-ZL]. Chone veleronis Banse, 1972, Paratypes [LACM-AHF POLY 0460].

\section{Description}

Colour, body shape and size: Body cream-colored. Trunk cylindrical, posterior abdomen depressed dorso-ventrally. Body length: $14 \mathrm{~mm}$ (531), width: $1 \mathrm{~mm}(0.4-1.5)$. Tubes unknown.

Branchial lobes and branchial crown: Insertion of the branchial crown not exposed beyond collar (Fig. 3A). Branchial crown length: $8 \mathrm{~mm}$ (6-10). Radioles: 9 pairs (6-11). Radiolar skeleton (rs) with two rows of cells. Distal pinnules longer than more proximal pinnules (Fig. 3E). Radiolar tips extra long (Fig. 3A, E). Palmate membrane (pm) extends about one quarter (Fig. 3F) or one half of the branchial crown length (but see remarks). Lateral flanges $(f l)$ very narrow (Fig. 3E). Dorsal lips $(\boldsymbol{d} \boldsymbol{l})$ extra long, 10 times longer than wide (Figs 3C-D), pear-shaped: rounded bulb basally, neck very long, erect, with a longitudinal median groove (Fig. 3D). Dorsal lips covered by glandular columnar epithelium (gce) and vascularised by a plexus of large and several blood vessels $(\boldsymbol{b} \boldsymbol{v})$ at the base (Fig. $3 \mathrm{M})$, then a large blood vessel runs along the structure towards the tip (Fig. $3 \mathrm{G})$. Dorsal lips filled with hyaline cartilage $(\boldsymbol{h c})$ (Fig. 3G), but there is no extension of the basal central skeleton (bcs) (Fig. 3D). Dorsal pinnular appendages: one pair united by a palmate membrane, shorter than dorsal lips length. Ventral lips ( $v \boldsymbol{l})$ rounded, small (Fig. 3D). Ventral radiolar appendages (vra): one pair, short, about one quarter of the branchial crown length (Fig. 3C).

Peristomium: Anterior peristomial ring lobe not exposed beyond collar (Fig. 3B), distally entire, triangular. Posterior peristomial ring collar: anterodorsal, ventral and lateral margins entire, ventral margin higher than dorsal (Fig. 3B); longitudinal grooves on dorsal, ventral and lateral sides of collar with dark glands along their axis, a narrow gap along the entire length of mid-dorsal collar margins (Fig. 3A). Dorsal pockets well developed. Ventral collar shield diffuse, indiscernible (Fig. 3B). Ratio of posterior peristomial ring collar length $v s$. chaetiger 2 length, in lateral view: 2:1.

Thorax: Chaetiger 1: two groups of elongate, narrowly hooded chaetae. Chaetigers 2 to 8 : Notopodia: superior group with two irregular rows of elongate narrowly hooded chaetae (Fig. 3I); inferior group with one anterior row of bayonet chaetae (Fig. 3L); two posterior rows with paleate chaetae with short mucro (Fig. 3H). Neuropodia: acicular 


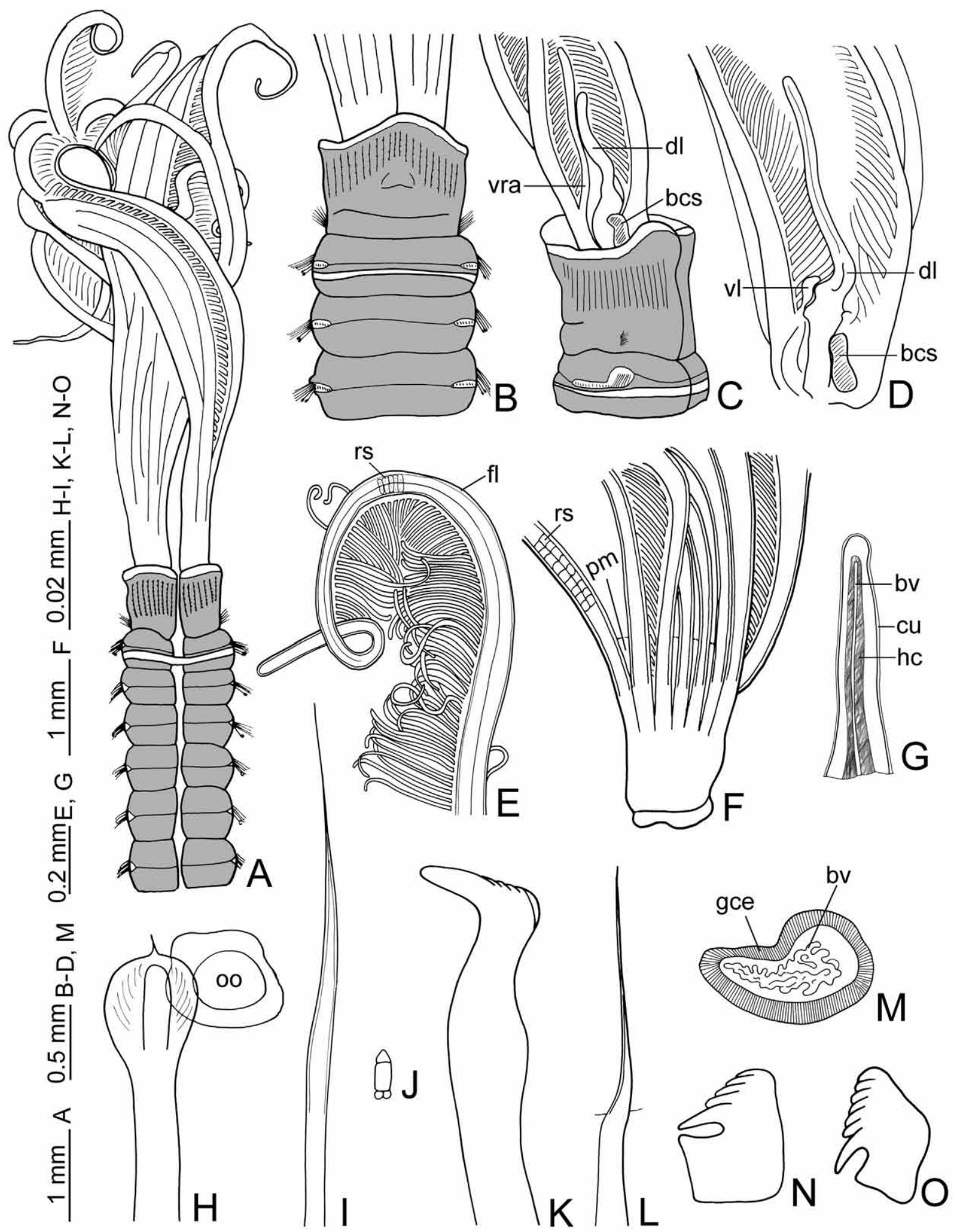

FIG. 3. - Chone acustica. A, anterior end, dorsal view; B, same, ventral view; C, same, lateral view; D, right, branchial lobe; E, radiolar tip; F, left, branchial lobe with radioles; G, tip of dorsal lip; H, paleate chaeta; I, thoracic, elongate narrowly hooded chaetae; J, spermatozoon; $\mathrm{K}$, thoracic uncinus; $\mathrm{L}$, bayonet chaeta; $\mathrm{M}$, base of the dorsal lip, transversal section; $\mathrm{N}$, anterior abdominal uncinus; O, posterior abdominal uncinus. A-C, methyl green staining pattern. A-B, E [Neotype, MNCN], D, J [Paratype, MNCN], C, F [PC-ZL 120, Foce di Tevere], G-I, KO [PC-ZL 121, Gulf of Salerno]. Abbreviations: $\boldsymbol{b c s}$ : basal, central skeleton, bv: blood vessel, cu: cuticle, dl: dorsal lip, fl: flange, gce: glandular columnar epithelium, $\boldsymbol{h} \boldsymbol{c}$ : hyaline cartilage, oo: oocyte, $\boldsymbol{p m}$ : palmate membrane, $\boldsymbol{r}$ : radiolar skeleton, $\boldsymbol{v l}$ : ventral lip, vra: ventral radiolar appendages. 
uncini distributed as a regular row, main fang surmounted by four rows of teeth equal in size, occupying less than half of the main fang length (Fig. $3 \mathrm{~K})$. Glandular ridge on chaetiger 2 narrow ventrally, broad dorsally. Thoracic segments biannulate. Pre- and post-chaetal lobes well developed.

Abdomen: Abdominal segments: 43 (27-44). Anterior segments: two transverse rows of elongate, narrowly hooded chaetae, upper row chaetae half as long as lower row ones; uncini with the main fang surmounted by four rows of teeth equal in size, occupying less than half of the main fang length, main fang not extending beyond breast (Fig. $3 \mathrm{~N}$ ). Posterior segments: very elongate, narrowly hooded chaetae, $25 \%$ longer than those of anterior segments; modified uncini with the main fang surmounted by 6-7 regular vertical rows of teeth equal in size, occupying three quarters of the main fang length, main fang not extending beyond breast, breast rectangular (Fig. 3O). Pygidium with rounded posterior margin.

Gametes: Paratype (MNCN) with spermatozoa with barrel-shaped nucleus, conical acrosome and two rounded mitochondria (Fig. 3J). Females from the Gulf of Salerno (PC-ZL 121) with polyhedric oocytes (oo) in thorax and abdomen (Fig. 3H).

Methyl green staining: Epidermis completely glandular stains uniformly in thorax and abdomen, dorsal, ventral and laterally (Figs 3A-C). The longitudinal grooves on the collar segment have dark rounded glands along their axis. The dorsal lips stain dark blue; the methyl green remains about 48 hours after staining. Pigmentation in the posterior end of the body is lost quickly.

Remarks: In this study, the designation of the neotype of Chone acustica (Claparède, 1870) is presented according to Arcticle 75.3.1 of the International Commission on Zoological Nomenclature (2000), since Claparède's collection is missing, making the recognition of his described taxa controversial. Chone acustica was described (as Dialychone) as lacking a palmate membrane; however, the recognition of the palmate membrane may be difficult in some instances. Thus, in specimens belonging to this species there may be a very low membrane connecting the radioles, just as a short extension from the branchial lobes or up to for a quarter of the branchial crown length as in Fitzhugh (1989), Knight-Jones et al. (1991) and Giangrande (1992) recorded in topotype materials.
For some specimens examined in this study, the palmate membrane extends along one half of the branchial crown length. The membrane could be easily broken due to the manipulation since, particularly in $C$. acustica, the membrane is extremely fragile and the flanges are very narrow. Hence, the presence and extension of the structure could be difficult to discern.

In old preserved materials the radioles are creamcolored, while in recent material they have red and white alternating bands; the red bands are cuticular, the white granulations are located inside each cartilaginous cell. This pattern also occurs in C. veleronis and $C$. perkinsi. Claparède described two otoliths in the peristomium; however, they are visible only when the collar is relaxed.

Chone acustica is unique among Mediterranean species by having a rudimentary rounded ventral collar shield, not easily discernible; short mucro and glandular ridge on chaetiger 2 broad dorsally (Table 1). Among the species of Chone two shapes of dorsal lips can be recognised: broadly rounded (as long as wide), or triangular (longer than wide, erect and elongated). The type species, $C$. infundibuliformis, has dorsal lips broadly rounded, as long as wide, without mid-rib; basally vascularised by a plexus of few, small blood vessels, but without branchial skeleton extensions (Tovar-Hernández and SosaRodríguez, 2006); such as is the case in $C$. aurantiaca, C.duneri, C. gracilis, C. letterstedti, C. magna, C. mollis and C. picta.

In comparison, the dorsal lips of C. acustica are pear-shaped (Figs 3C-D), with a small and rounded basal bulb, and very long neck (ten times longer than the bulb), with a groove running along their length (not as mid-rib). Internally, dorsal lips are basally vascularised by a plexus of several large blood vessels, and then one vessel runs along the neck (Fig. 3G), but there is no extension of the branchial skeleton. Other species with this internal features and elongate dorsal lips are: C. albocincta, C. americana, C. arenicola, C. bimaculata, C. collaris, C. diazi, C. ecaudata, C. farringtonae, $C$. johnstonae, C. longiseta, C. perkinsi, C. uebelackerae, C. usticensis, C. veleronis, and an undescribed species from the Pacific coast of Panama.

In the type species, Chone infundibuliformis, the anterior and posterior abdominal uncini are similar in shape (Tovar-Hernández and Sosa-Rodríguez, 2006). However, C. acustica has modified, posterior abdominal uncini (as rasp-shaped plates or Amphicorina- 
CHONE FROM THE EASTERN CENTRAL ATLANTIC AND MEDITERRANEAN • 321

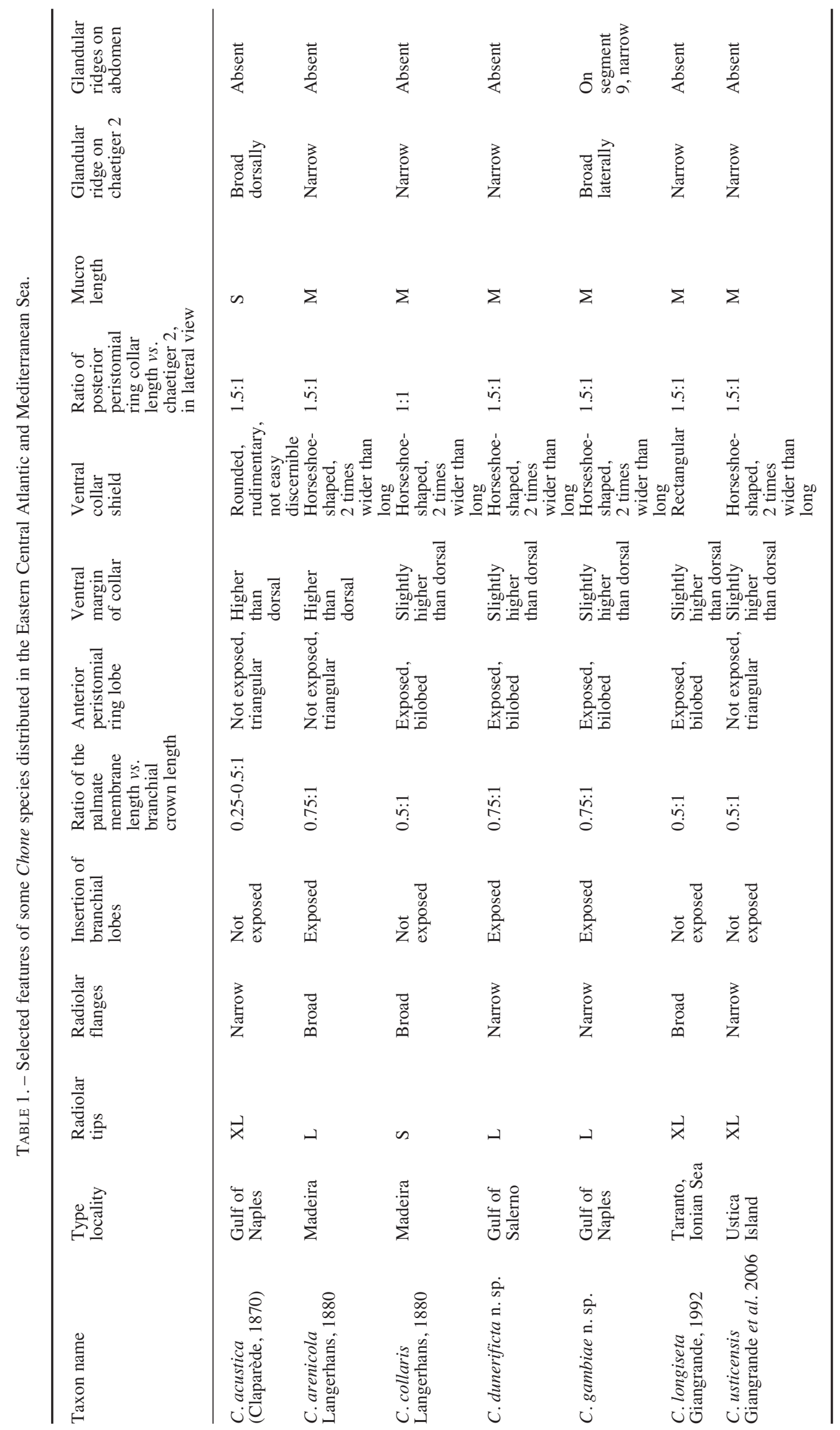


type). This kind of modified uncini has a main fang surmounted by several regular, vertical rows of small equal in size teeth that occupy at least three quarters of the main fang length, and a poorly developed rectangular or sub-rectangular breast, instead of a few rows of unequal in size teeth occupying less than half of the main fang length, and a well developed breast, as anterior segment uncini (Tovar-Hernández and Sosa-Rodríguez, 2006).

Distribution and habitat: Widely distributed in the Mediterranean Sea in shallow, sandy-bottoms.

\section{Chone arenicola Langerhans, 1880}

(Fig. 4)

Chone arenicola Langerhans, 1880: 115-116, Fig. 28a-g. Giangrande, 1992: 523-524, Figs. 10a-d, 11a-e, 12a-e.

Type material: Syntype [NHMW 2286] Madeira, Ak IVr 1884/XIV/191, Alte, Prof. Langerhans.

Non-type material: La Gomera, Canary Archipelago [DZUL] M-7 P1, UTM 293140 X/31113800 Y, medium sand, D50 medium, $0.25 \mathrm{~mm}, 15 \mathrm{~m}$, Coll. Tecnología Ambiental S.A., August 1995 (1); M7 P3 (2). M-103, UTM 269695/3109515, 14 m, Coll. Tecnología Ambiental S.A., August 1995 (3). M-104, UTM 269570/3109515, 15 m, Coll. Tecnología Ambiental S.A., August 1995 (2). M-116, UTM 269695/3100715, $30 \mathrm{~m}$, fine sand, D50 medium, $0.24 \mathrm{~mm}$, in Cymodocea nodosa prairies, Coll. Tecnología Ambiental S.A., August 1995 (2). M-136, UTM 272195/3104750, 15 m, fine sand, D50 medium, $0.23 \mathrm{~mm}$, in Cymodocea nodosa prairies, Coll. Tecnología Ambiental S.A., August 1995 (1). M-141, UTM 284205/3101210, 35 m, Coll. Tecnología Ambiental S.A., August 1995 (1). M-144, UTM 284335/3101365, $30 \mathrm{~m}$, fine sand, D50 medium, $0.27 \mathrm{~mm}$, in Cymodocea nodosa prairies, Coll. Tecnología Ambiental S.A., August 1995 (1). Tyrrhenian Sea [PC-ZL] 113 Gulf of Salerno, 1982, -20 m (1). Gulf of Naples [LEB] Portici, $40^{\circ} 49^{\prime} \mathrm{N}, 14^{\circ} 19.28^{\prime} \mathrm{E}, 2002$, 9-10 m (5); Portici, 4049' N, $14^{\circ} 19.28^{\prime}$ E, 2003, -9 m (1); Portici, 4049' N, 14¹9.28' E, August 2004, -9 m (5); Portici, 4049’ N, 14²19.28' E, November 2004, -9 m (1); Napoli, Castel dell'Ovo, 4049.43' N, 14²14.35' E, February 2004, -11 m (3); Napoli, Castel dell'Ovo, 4049.43' N, 14¹4.35' E, August 2004, -8 m (1); Napoli, Castel dell'Ovo, 4049.43' N, $14^{\circ} 14.35^{\prime}$ E, 2005, -8 m (3).

Additional material: Chone perkinsi Tovar-Hernández, 2005, Paratype [ECOSUR 0053]. Chone veleronis Banse, 1972, Paratypes [LACM-AHF POLY 0460].

\section{Description}

Color, body shape and size: Body and base of the branchial crown cream-colored. Radioles with irregular purple lateral spots in the radiolar axis skeleton, on flanges (not in the rachis), and colour extends into the pinnules (Fig. 4I). Trunk cylindrical, posterior abdomen depressed dorso-ventrally. Body length: $4 \mathrm{~mm}$ (5.5-12), width: $0.5 \mathrm{~mm}(0.4-0.7)$. Tubes unknown.

Branchial lobes and branchial crown: Insertion of the branchial lobes exposed beyond collar dorsally. Branchial crown length: $4 \mathrm{~mm}$ (2.5-3). Radioles:
6 pairs (5-6). Radioles with pinnules of equal length, each radiole has 3-5 dark spots on the flanges surrounding the cartilaginous skeleton of the radiolar axis (Figs 4A, I). Radiolar tips long. Palmate membrane extends up to three quarters of the branchial crown length. Lateral flanges $(f l)$ broad (Fig. 4I). Dorsal lips triangular, erect, three times longer than wide, without mid-rib. Dorsal pinnular appendages: one short pair, united by a palmate membrane. Ventral lips rounded, about three quarters of the dorsal lips length. Ventral radiolar appendages: two pairs (1-2), as long as one quarter of the branchial crown length.

Peristomium: Anterior peristomial ring lobe not exposed beyond collar (Fig. 4A), distally entire, triangular. Posterior peristomial ring collar: dorsal, ventral and lateral margins entire, ventral margin higher than dorsal (Fig. 4C); longitudinal grooves on lateral sides of collar; entire length of mid-dorsal collar margins forms a narrow gap. Dorsal pockets well developed. Two dorsal peristomial otoliths. Ventral collar shield horseshoe-shaped, three times wider than long (Figs 4A-B), with two postero-lateral grooves. Ratio of posterior peristomial ring collar length $v s$. chaetiger 2 length, in lateral view: 1.5:1.

Thorax: Chaetiger 1: two groups of four elongate, narrowly hooded chaetae. Chaetigers 2 to 8 : Notopodia: superior group with two irregular rows of three elongate, narrowly hooded chaetae; inferior group with one anterior row with bayonet chaetae (Fig. 4F); two posterior rows with paleate chaetae with medium-sized mucro (Fig. 4G). Neuropodia: acicular uncini distributed as a regular row, main fang surmounted by 3-4 rows of teeth in frontal view, equal in size, occupying half of the main fang length (Fig. 4H). Narrow glandular ridge on chaetiger 2. Thoracic segments biannulate.

Abdomen: Abdominal segments: 33 (28-43). Anterior segments: two transverse rows of elongate, narrowly hooded chaetae, upper row chaetae half as long as lower row ones; uncini with the main fang surmounted by 4-5 regular rows of equal in size teeth in frontal view, occupying one half of the main fang length, main fang not extending beyond breast, breast rectangular (Figs 4J-K). Posterior segments: 1-2 very elongate, narrowly hooded chaetae, $25 \%$ longer than in anterior segments (Fig. 4E); modified uncini with the main fang surmounted by 6-7 regular vertical rows of equal in size teeth, occupying three quarters of the main fang length, main fang not extending beyond breast, breast rectangular (Figs 


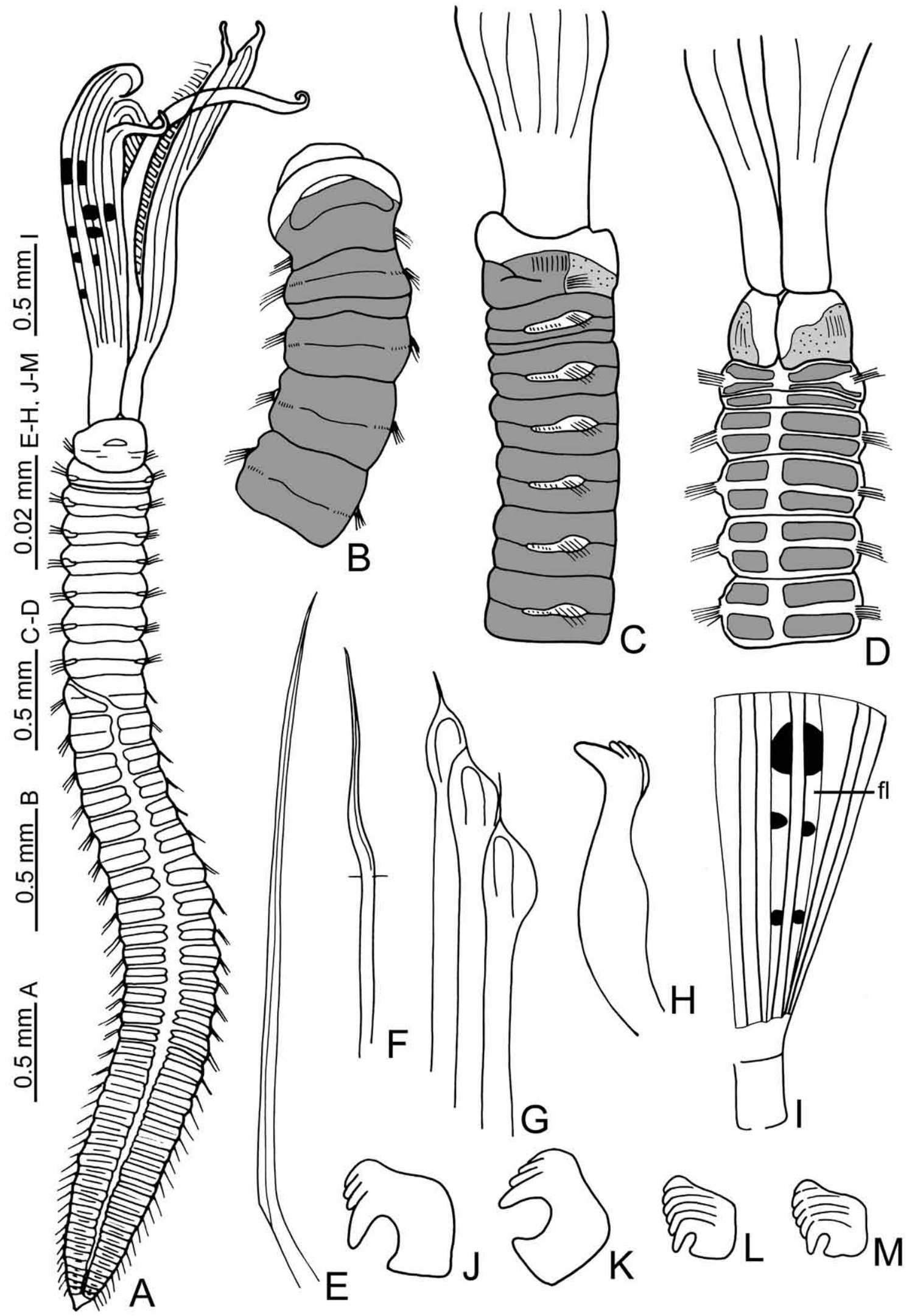

FIG. 4. - Chone arenicola. A, body, ventral view; B, anterior end, ventral view; C, same, lateral view; D, same, dorsal view; E, elongate, narrowly hooded chaeta from collar; F, bayonet chaeta; G, paleate chaetae; H, thoracic uncinus; I, right, branchial lobe with radioles; J-K, anterior abdominal uncini; L-M, posterior abdominal uncini. B-D, methyl green staining pattern. A-M [DZUL, Gomera]. Abbreviations: fl: flange. 
4L-M). Pygidium with triangular posterior margin, small cirrus, not easily discernible (Fig. 4A).

Gametes: Not seen in syntype, non-type materials immature.

Methyl green staining: Anterior half of the collar not coloured (Figs 4B-C). Ventrally, the posterior half of collar stains uniformly (Fig. 4B); dorso-laterally less coloured with small dark spots (Fig. 4D). The anterior margin of the ventral collar shield not coloured (Fig. 4B). Thorax and anterior abdomen with epidermis completely glandular, stains uniformly, dorsal and ventrally. Posterior abdomen not coloured, only spread, dark spots are present. Pygidium darker, after being returned to ethanol for some days, it remains stained.

Remarks: Langerhans (1880: 115) noted the average measurements of $C$. arenicola indicating that he had originally examined more specimens than two; however, only one syntype was deposited in the Museum of Natural History in Vienna. The syntype is partially dried, broken, lacks a branchial crown and is mounted in a micro slide. However, the original description and drawings of $C$. arenicola permit the unequivocal identification of specimens well distributed in the Mediterranean Sea and eastern central Atlantic.

The radioles of $C$. arenicola have irregular lateral purple spots in the radiolar axis skeleton, on flanges (not in the rachis), and colour extends into the pinnules. In other species, such as $C$. perkinsi and $C$. veleronis, the radioles have coloured bands along the radiolar axis, but not in the flanges, and as in $C$. arenicola, the colour extends into the skeletal cells of the pinnules. However, in these species the radiolar colour pattern is observed only in fresh or recently preserved specimens.

Chone arenicola, $C$. gambiae $\mathrm{n}$. $\mathrm{sp}$. and $C$. dunerificta $\mathrm{n}$. sp. have the insertion of the branchial lobes exposed beyond collar; however, the anterior peristomial ring lobe is triangular, not exposed beyond collar in $C$. arenicola (bilobed and exposed in C. gambiae n. sp., and in C. dunerificta n. sp.) (Table 1). The anterior peristomial ring is exposed in all specimens examined, but a small variation in the degree of the exposition of the peristomium due to the fixation process is observed.

Distribution and habitat: eastern central Atlantic Ocean and Mediterranean Sea, in shallow sandybottom.
Chone collaris Langerhans, 1880

(Fig. 5)

Chone collaris Langerhans, 1880: 116, Fig. 29a-f. Knight-Jones et al. 1991: 850. Giangrande, 1992: 524-525, Figs 13a-f, 14a-d.

Material examined

Type material: Syntypes (4) [NHMW 1966, 2287] Madeira, 1884, XVI, 193, Prof. Langerhans.

Non-type materials: Lanzarote, Puerto Calero, Canary Archipelago [DZUL] R1 P1, UTM 625400 X/3199080 Y, 4 m, rocky bottom covered by the algae Stypocaulon scoparium, Coll. O. Monterroso and M. Rodríguez, among Syllis prolifera and Bittium latreillii, October 25, 2004 (3). R4 P2, UTM 628165 X/3199080 Y, $4 \mathrm{~m}$, rocky bottom covered by the algae Stypocaulon scoparium, Coll. O. Monterroso and M. Rodríguez, among Platynereis dumerilli and Syllis prolifera, October 24, 2004 (4); R4 P3 (2).

Additional materials: Chone duneri Malmgren, 1867, Topotypes [ZMUC POL-1755]. Chone longiseta Giangrande, 1992, Topotypes [PC-ZL 142].

\section{Description}

Colour, body shape and size: Body browncoloured. Trunk cylindrical, posterior abdomen depressed dorso-ventrally (Fig. 5A). Body length: $3.5 \mathrm{~mm}$ (1.8-5), width: $0.4 \mathrm{~mm}$ (0.3-0.5).

Branchial lobes and branchial crown: Insertion of the branchial lobes not exposed beyond collar. Branchial crown length: $1.75 \mathrm{~mm}$ (0.8-1.5). Radioles: 5 pairs (4-5). Radioles with pinnules of similar length. Radiolar tips short (Fig. 5D). Palmate membrane extends up to one half of the branchial crown length. Lateral flanges broad (Fig. 5D). Dorsal lips triangular, erect, two times longer than wide, with a groove along dorsal margin. Dorsal pinnular appendages: one short pair. Ventral lips about one quarter the length of dorsal lips, broadly, distally rounded. Ventral radiolar appendages $(\boldsymbol{v r a})$ : 4 pairs, longest appendages about as long as the branchial crown, the shortest about the collar length (Fig. 5C).

Peristomium: Anterior peristomial ring lobe (aprl) exposed beyond collar, distally bilobed (Fig. $5 \mathrm{C}, \mathrm{E})$. Posterior peristomial ring collar: dorsal, ventral and lateral margins of collar entire, crenulated (Figs 5A-C, E-F). Entire length of mid-dorsal collar margins forms a narrow gap. Dorsal pockets well developed. Ventral collar shield (vsc) swollen, horseshoe-shaped, two times wider than long (Fig. $5 \mathrm{~F})$. Ratio of posterior peristomial ring collar length $v s$. chaetiger 2 length, in lateral view: $1: 1$. Rounded peristomial eyespots (pe), unequal size (Figs 5A-C).

Thorax: Chaetiger 1: two groups of 3-4 elongate, narrowly hooded chaetae. Chaetigers 2 to 8 : Notopodia: superior group with two irregular rows of four elongate narrowly hooded chaetae; inferior 


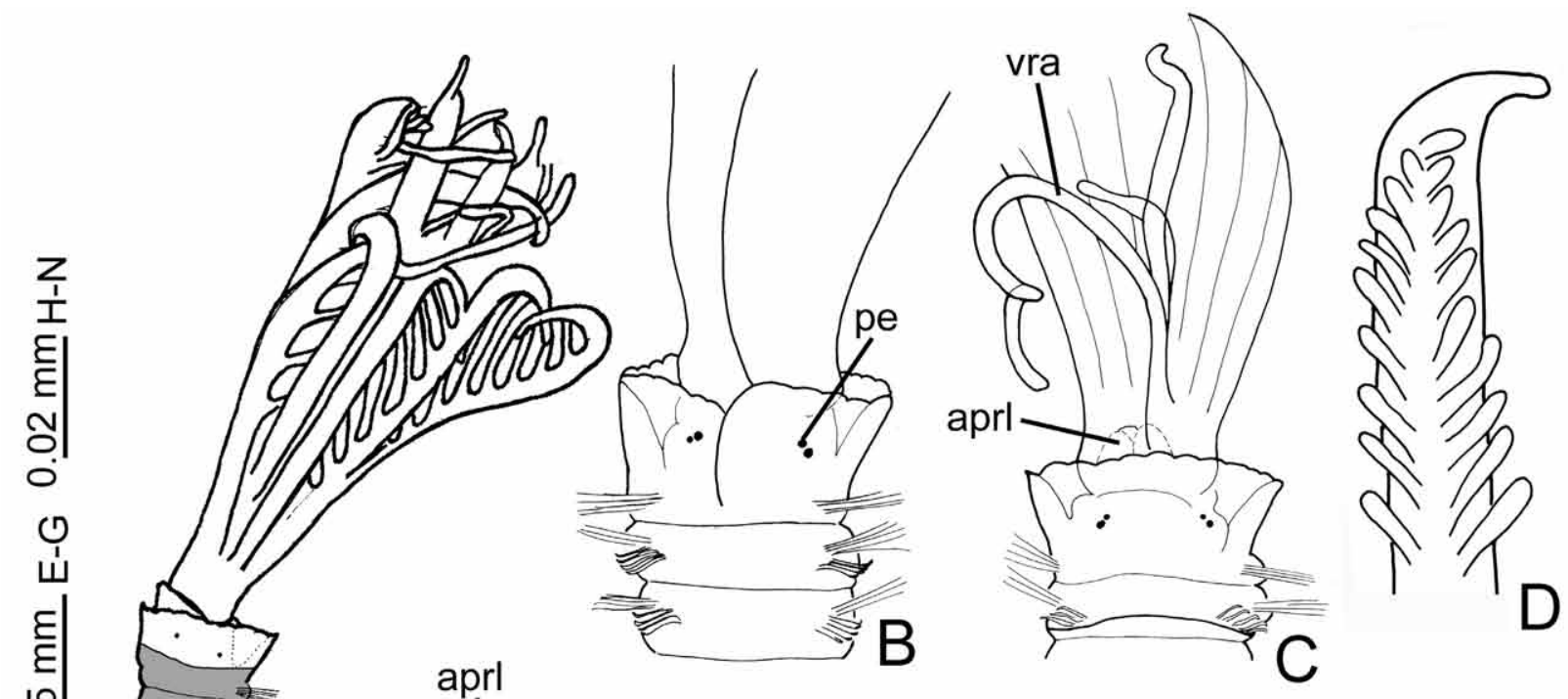

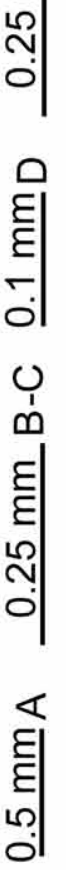
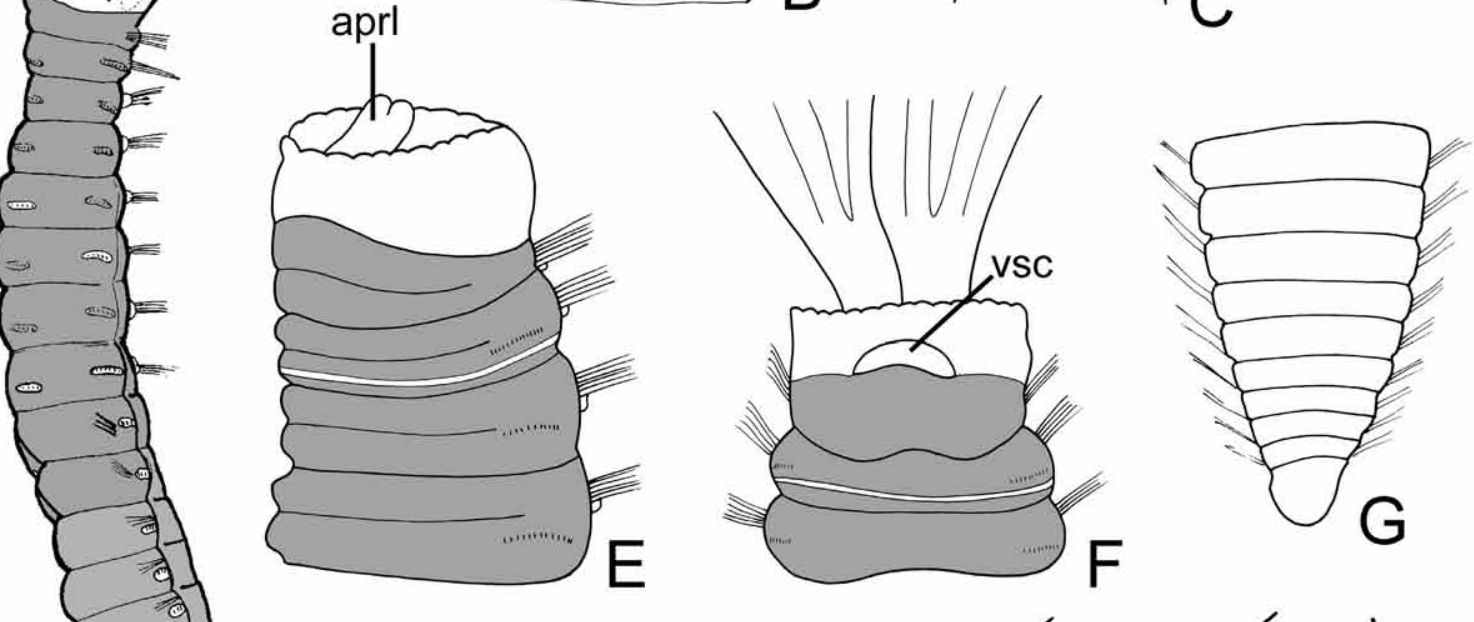

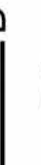
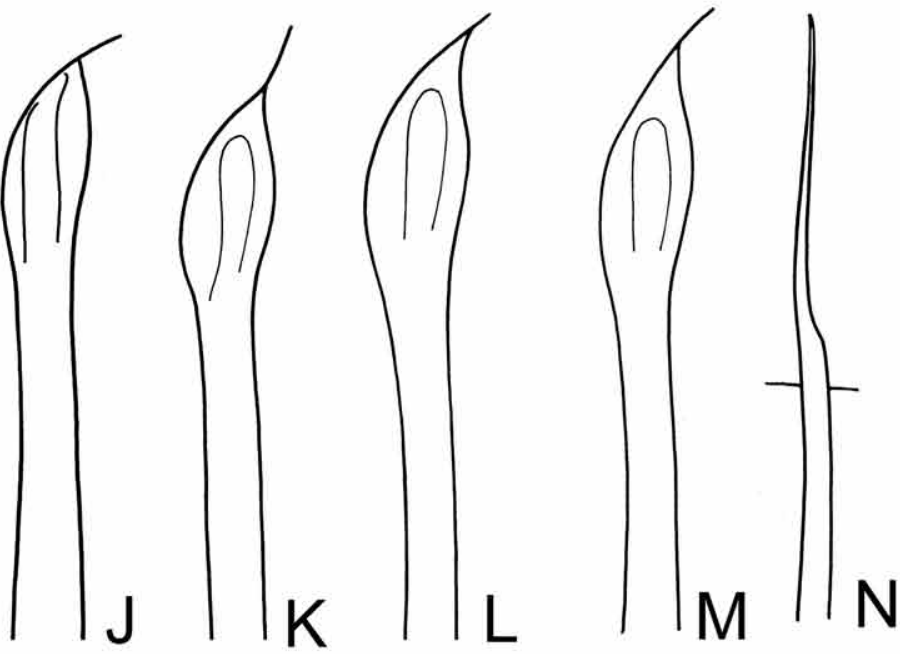

FIG. 5. - Chone collaris. A, body, lateral view, B, anterior end, dorsal view; C, F, same, ventral view; D, radiolar tip; E, anterior end, lateral view; G, posterior abdomen; H, anterior abdominal uncinus; I, posterior abdominal uncinus; J-M, paleate chaetae; N, bayonet chaeta. A, EF, methyl green staining pattern. A-D, J [Syntype, NHMW 2287], E-I, K-N [DZUL, Puerto Catero, Lanzarote]. Abbreviations: aprl: anterior peristomial ring lobe, pe: peristomial eyes, vra: ventral radiolar appendages, vsc: ventral collar shield.

group with four short, bayonet chaetae (Fig. 5N); two posterior rows with four paleate chaetae with medium-sized mucro (Fig. 5J-M). Neuropodia: one row of 10 (8-9) acicular uncini per torus, main fang surmounted by four rows of small teeth, equal in size, occupying half of the main fang length. Narrow glandular ridge on chaetiger 2. Thoracic segments biannulate. 
Abdomen: Abdominal segments: 22 (22-23). Anterior segments: two transverse rows of elongate narrowly hooded chaetae, upper row chaetae half as long as lower row ones; uncini with the main fang surmounted by 3-4 rows of teeth equal in size, occupying less than half of the main fang length, main fang not extending beyond breast, breast rectangular (Fig. 5H). Posterior segments: three very elongate narrowly hooded chaetae, $25 \%$ longer than those of anterior segments; 3-5 modified uncini per torus, main fang surmounted by 7-8 teeth above the main fang (Fig. 5I). Pygidium with rounded posterior margin (Fig. 5G), with small eyespots in one syntype.

Gametes: One syntype male, spermatozoa with rectangular acromose and two rounded small mitochondria; one syntype female with small eggs in a little incision between thorax and abdomen; sex for other syntypes undeterminable.

Methyl green staining: Ventrally, the epidermis is completely glandular and stains uniformly in thorax and abdomen (Figs 5E-F). Dorsally and laterally, no colour is retained, except in the second chaetiger.

Remarks: Four original syntypes of Chone collaris (Langerhans NHMW 1966, 2287) were examined. All specimens have the anterior margin of the collar crenulated, which agrees with Langerhans's original collar illustration (Fig. 29b).

Chone collaris is unique among Chone species in having the anterior margin of the collar crenulated; however, this feature is homoplastic, being found in many species of Amphicorina (Rouse, 1994). Knight-Jones et al. (1991) recorded C. collaris from Turkey's Aegean coast; they compared it with material from the North Sea, in which the collar is crenulated too, but the radioles have reduced flanges and very long filamentous tips. The ratio of posterior peristomial ring collar length $v s$. chaetiger 2 length, in lateral view is $1: 1$ in $C$. collaris in comparison with $C$. acustica, $C$. arenicola, $C$. longiseta, $C$. usticensis, $C$. gambiae n. sp., and $C$. dunerificta n. sp., in which this ratio is 1.5:1 (Table 1). Chone longiseta (described from Taranto), and $C$. duneri (described from Norway) resemble $C$. collaris in that the anterior peristomial ring lobe is bilobed and exposed beyond collar; however, C. collaris has peristomial eyes (absent in $C$. longiseta and $C$. duneri), and short radiolar tips (extra long in $C$. longiseta and C. duneri).
Distribution and habitat: eastern central Atlantic Ocean and Mediterranean Sea, typical of photophilic algae of shallow waters, and it can occasionally be found in sandy bottoms.

\section{Chone duneri Malmgren, 1867}

(Fig. 6)

Chone duneri Malmgren, 1867: 225, Pl. 14, Fig. 75a-d. Langerhans, 1880: 114-115, Figs 44a-e. Hofsommer, 1913: 336-339. Southern, 1914: 141. Wessenberg-Lund, 1950: 58. Pettibone, 1954: 339. Eliason, 1962: 89-91. Hartmann-Schröder, 1971: 517. Banse, 1972: 466, fig. 2a-b. Kirkegaard, 1996: 372-374.

Material examined: [LACM-AHF] Arctic Ocean, Beaufort Sea, Northwest of Cape Halkett, Alaska, Coll. Andrew Carey: SMG-1088 (1), SMG-1090 (1), SMG-1091 (1), Sta. PP-0055, 71-19 N, 152-34 W, 59 m, 29 October 1975, Cruise OCS-1, Helicopter sampling; SMG-1123 (5), SMG-1126 (1), 71-17.3 N, 152-41.3 W, 58 m, 18 March 1976, Cruise OCS-2, Helicopter sampling. SMG-1139 (6), SMG-1140 (1), SMG-1155 (3), SMG-1156 (2), SMG-1158 (1), SMG-1159 (2), SMG-1160 (1), Sta. PP-0100, 71-26.3 N, 152-38.4 W, 99 m, 19 March, 1976, Cruise OCS-2, Helicopter sampling. SMG-1151 (6), Sta. PP-0055, 71-18 N, 152-41.1 W, 55 m, 20 May 1976, Cruise OCS-3, Helicopter sampling. SMG-1161 (5), SMG-1162 (2), SMG-1166 (2), SMG-1168 (4), SMG-1169 (8), Sta. PP-0100, 71-19.3 N, 152-39.1 W, $101 \mathrm{~m}$, 21 May 1976, Cruise OCS-3, Helicopter sampling. SMG-1318 (3), Sta. PP-0100, 71-22.4 N, 152-23 W, 92 m, 30 August 1976, Cruise OCS-4, Ship WAGB-Glacier; SMG-1319 (4), 71-22.3 N, 152-22.5 W, $90 \mathrm{~m}$; SMG-1322 (1), 71-22.2 N, 152-21.5 W, $84 \mathrm{~m}$; SMG-1323 (1), 71-22.2 N, 152-21.3 W, 83 m; SMG-1491 (1), SMG-1494 (6), 71-21.5 N, 152-33.2 W, 99 m, 3 November 1976, Cruise OCS-6, Helicopter sampling. SMG-1495 (1), SMG-1496 (1), Sta. PP-0055, 71-17.3 N, 152-43.2 W, 53 m, 4 November 1976, Cruise OCS-6, Helicopter sampling. SMG-1541 (3), 71-19 N, 152-50 W, 54 m, 11 August 1977, Cruise OCS-7, Ship WAGB-Glacier; SMG-1542-05 (4), SMG-1543 (2), 71-19 N, 152-52 W, $52 \mathrm{~m}, 11$ August 1977, Cruise OCS-7, Ship WAGB-Glacier; SMG-1546 (1), Sta. PP-0055, 71-19.3 N, 152-58 W, $55 \mathrm{~m}, 11$ August 1977, Cruise OCS-7, Ship WAGB-Glacier. SMG-1702 (2), SMG-1703 (1), Sta. PP-0055, 71-18 N, 152-48 W, $55 \mathrm{~m}, 24$ August 1978, OCS-8, USCGC Northwind; SMG-1704 (2), Sta. PP-0055, 71-18.5 N, 152-49.1 W, 54 m, 24 August 1978, Cruise OCS-8, USCGC Northwind; SMG-1705 (1), 71-19 N, 152-50 W, 55 m, 24 August 1978, USCGC Northwind; SMG-1715 (2), SMG-1716 (1), Sta. PP-0100, 71-21 N, 152-41 W, 98 m, 24 August 1978, Cruise OCS-8, USCGC Northwind. Sweden [LACM-AHF] LH02-366 (1), off Tjarno Marine Station, Kosterfjord, S. Vattenholm, $58^{\circ} 52.27^{\prime} \mathrm{N}, 11^{\circ} 6.3^{\prime} \mathrm{E}$ to $58^{\circ} 52.11^{\prime} \mathrm{N}$, $11^{\circ} 6.54^{\prime} \mathrm{E}, 113 \mathrm{~m}$ to $110 \mathrm{~m}$, silt and clay, 10 April, 2002, R/V Nereus, biological dredge with $1 \mathrm{~mm}$ end mesh, Coll. Arne Nygren and Leslie Harris. LH02-418 (1) off Tjarno Marine Station, $58^{\circ} 52.11^{\prime} \mathrm{N}, 11^{\circ} 5.28^{\prime} \mathrm{E}$ to $58^{\circ} 52.05^{\prime} \mathrm{N}, 1^{\circ} 5.33^{\circ} \mathrm{E}, 217 \mathrm{~m}$ to $54 \mathrm{~m}$, mud, 15 April, 2002, R/V Nereus, biological dredge with $1 \mathrm{~mm}$ end mesh, Coll. Arne Nygren and Leslie Harris. Greenland [ZMUC POL-1755] Bugten avefor rode $\varnothing$ i Rodr Fjord, 3 Year East Greenland Exp. Sta. 3315-20 m, August 22, 1933 (54). Scotland [NMW.Z] Calback Ness and Little Roe, Sullom Voe, Shetland Isles: 1998.062.0062, Sta. B48, K, medium sand, 32 m, IOE, April 1988 (12).

Additional material: Chone bimaculata Banse and Nichols, 1968, Paratypes [USNM 36280]. Chone uebelackerae Tovar-Hernández, 2005, Paratypes [FSBC I 34709].

Description (based on Norwegian specimens)

Colour, body shape and size: Body cream coloured, trunk cylindrical (Figs 6D, G), abdomen 

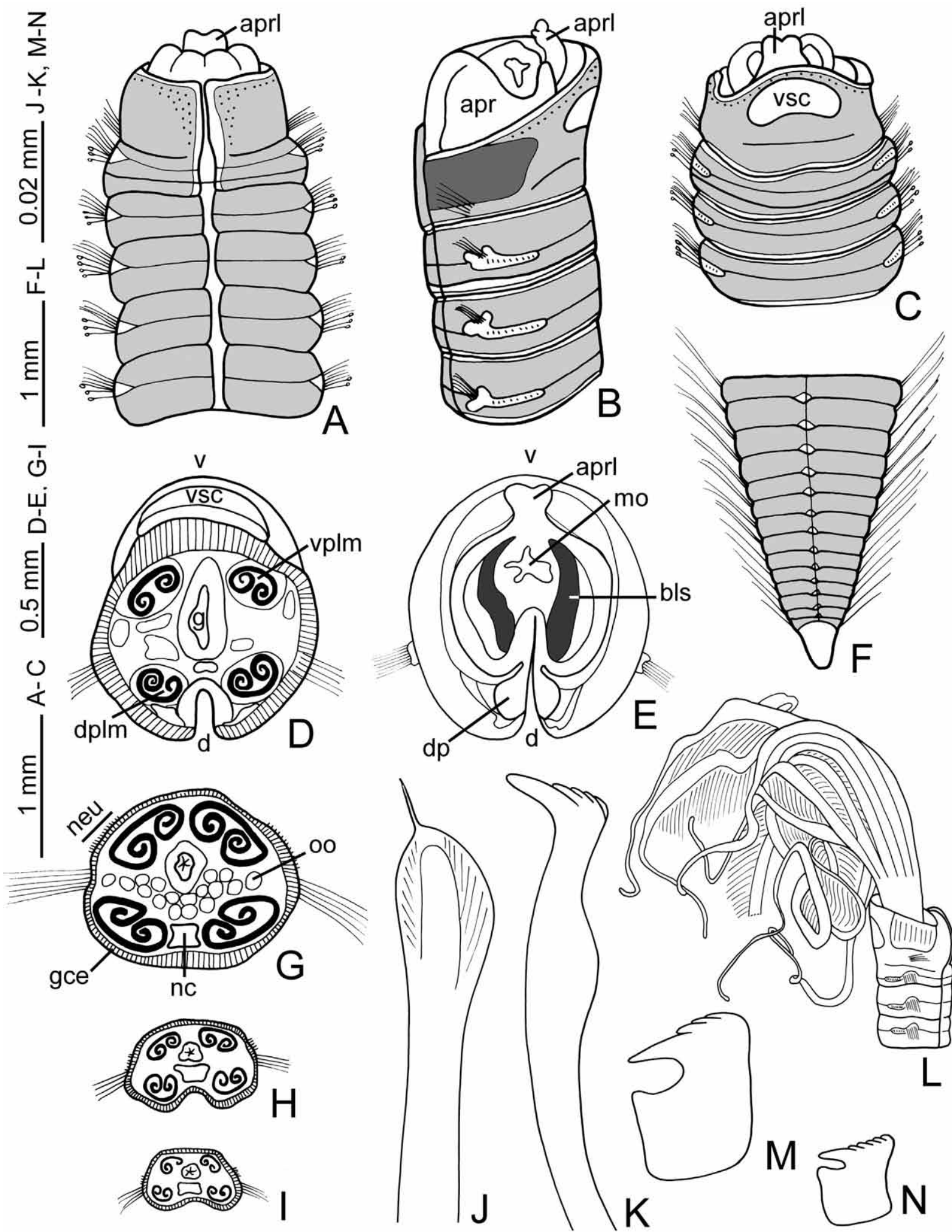

FIG. 6. - Chone duneri. A, anterior end, dorsal view; B, same, lateral view; $\mathrm{C}$, same end, ventral view; D, transversal section on collar segment; E, collar, frontal view; F, posterior abdomen; G, transversal section on posterior thorax; $\mathrm{H}$, transversal section on anterior abdomen; I, posterior section on posterior abdomen; J, paleate chaeta; K, thoracic uncinus; L, anterior end, lateral view; M, anterior abdominal uncinus; N, posterior abdominal uncinus. A-C, F, methyl green staining pattern. A-C, F, J-K, M-N [LACM-AHF, Beaufort Sea, SGM 1168]; D-E, GI [LACM-AHF, Beaufort Sea, SMG 1318], L [ZMUC 1755, Rodr Fjord]. Abbreviations: apr: anterior peristomial ring, aprl: anterior peristomial ring lobe, $\boldsymbol{b l s}$ : basal lateral skeleton, $\boldsymbol{d}$ : dorsum, $\boldsymbol{d}$ : dorsal pockets, $\boldsymbol{d p l m}$ : dorsal package of longitudinal muscle, gce: glandular columnar epithelium, $\boldsymbol{m o}$ : mouth, $\boldsymbol{n c}$ : nerve cord, $\boldsymbol{n e u}$ : neurochaetae, $\boldsymbol{o o}$ : oocytes, $\boldsymbol{v}$ : ventrum, $\boldsymbol{v p l m}$ : ventral package of longitudinal muscle, $\boldsymbol{v s c}$ : ventral collar shield. 
depressed with pronounced faecal groove (Figs 6HI). Body length: $11-13 \mathrm{~mm}$, width: $1.5 \mathrm{~mm}$. Tubes composed of fine sand.

Branchial lobes and branchial crown: Insertion of the branchial lobes exposed beyond collar (Figs 6A-C). Branchial crown length: 7-8 mm. Radioles: 10-12 pairs. Radioles with median pinnules three times longer than proximal ones. Radiolar tips extra long (Fig. 6L). The palmate membrane extends about three quarters of the branchial crown length. Lateral flanges broad. Dorsal lips broadly rounded in frontal view, as long as wide, without mid-rib, resemble the ventral lips, longer than wide in dorsolateral view. Dorsal pinnular appendages: one pair about one quarter of the branchial crown length, united by a palmate membrane. Ventral lips rounded, as long as wide, about one quarter of the dorsal lips length. Ventral radiolar appendages: 3 pairs about one half of the branchial crown length.

Peristomium: Anterior peristomial ring lobe (aprl) exposed beyond collar, distally bilobed (Figs 6A-C, E). Posterior peristomial ring collar: anterodorsal margins entire (Fig. 6A), forming two well developed dorsal pockets (dp) (Fig. 6E); otoliths in dorsal pockets; entire length of mid-dorsal collar margins forms a narrow gap (Fig. 6A); lateral and ventral margins entire (Figs 6B-C); ventral margin higher than dorsal (Fig. 6B). Ventral collar shield (vsc) swollen, horseshoe-shaped, twice wider than long (Figs 6C-D). Ratio of posterior peristomial ring collar length $v s$. chaetiger 2 length, in lateral view: 1.5:1 (Fig. 6B).

Thorax: Chaetiger 1: two groups of eight elongate, narrowly hooded chaetae. Chaetigers 2 to 8 : Notopodia: two rows of elongate, narrowly hooded chaetae; one anterior row with bayonet chaetae, two posterior rows with symmetrical, paleate chaetae with medium mucro (Fig. 6J). Pre- and post-chaetal lobes well developed (Fig. 6B). Neuropodia: two irregular rows of acicular uncini, heads in the same direction, the oldest upper parts of the torus have only one row (one quarter of the tori length), main fang surmounted by four rows of teeth, occupying one half the main fang length (Fig. 6K); second tooth enlarged, located in the midline. Narrow glandular ridge on chaetiger 2 . Thoracic segments biannulate.

Abdomen: Abdominal segments: 42-44. Anterior segments: two transverse rows of elongate, narrowly hooded chaetae, upper row chaetae half as long as lower row ones; uncini with the main fang sur- mounted by four rows of equal sized teeth, occupying one half of the main fang length, older (dorsalmost) uncini smaller than younger uncini (ventralmost), main fang not extending beyond breast, breast rectangular (Fig. 6M). Posterior segments: 12 very elongate, narrowly hooded chaetae; uncini similar to those in anterior abdomen, smaller (Fig. $6 \mathrm{~N})$. Pygidium with triangular posterior margin (Fig. 6F).

Gametes: Small, abundant oocytes (oo) in thorax and abdomen (ZMUC POL-1755) (Fig. 6G).

Methyl green staining: Thorax and abdomen stains uniformly, dorsal and ventrally (Fig. 6A-C). The collar segment is darker on lateral sides (Fig. 6B), the ventral collar shield unstained (Fig. 6C).

Remarks: Banse (1972: 466) synonymised $C$. bimaculata with $C$. duneri because the main reason for describing C. bimaculata was the presence of a glandular ridge on chaetiger 2, but this structure is a shared characteristic of Chone, Euchone and Jasmineira, group called "Chonea" after phylogenetic analyses by Cochrane (2003). Chone bimaculata is recognised as a valid species on the basis that it has unique features and differs from $C$. duneri. Both species have the insertion of the branchial lobes and the bilobed anterior peristomial ring lobe exposed beyond collar, and radiolar tips extra long (comprising approximately a third of the length of radioles). Chone bimaculata differs from $C$. duneri in that lateral flanges are narrow (broad in $C$. duneri); the antero-dorsal margin of posterior peristomial ring collar is incised (not incised in $C$. duneri); the entire length of mid-dorsal collar margins forms two prominent lobes, covering a narrow gap (broad gap in C. duneri); the anterior peristomial ring collar is partially exposed beyond collar dorsally (completely exposed in $C$. duneri); the ventral collar shield is trapezoid-shaped (horseshoe-shaped in $C$. duneri); modified posterior abdominal uncini (anterior and posterior abdominal uncini similar in C. duneri), and pygidium with rounded posterior margin (triangular in C.duneri).

Distribution: Chone duneri was described from Spitzbergen (Norway) but has been regarded as having a very wide distribution: Madeira (Langerhans, 1880), North Sea (Hofsommer, 1913), Ireland (Southern, 1914), Alaska (Pettibone, 1954), Washington (Banse, 1972), Florida, Gulf of Mexico, and the Caribbean (Perkins and Savage, 1975), 
Colombia (Rodríguez-Gómez, 1988), Mexican Caribbean (Jiménez-Cueto and Salazar-Vallejo, 1991), Italian coasts (Giangrande, 1992), and Pechora Sea (Dahle et al. 1998, Cochrane, 2000); however, most of the records contain discrepancies in the diagnostic characters observed (Sabine Cochrane pers. com.).

According to Cochrane (2000), only the materials from the Pechora Sea (in the southeastern, and northern parts of the Barents Sea) agree with the original description, and with the redescription by Hofsommer (1913) (Jutland). The present study shows that the distribution of this species is restricted to the Arctic Ocean. Thus, the records from the Mediterranean Sea of Giangrande (1992) correspond to a new species herein described as Chone dunerificta $\mathrm{n}$. sp.; the record for the Mexican Caribbean (Jiménez-Cueto and Salazar-Vallejo, 1991) corresponds to C. uebelackerae; the specimens from Colombia of Rodríguez-Gómez (1988) were not available, but the drawings and descriptions do not correspond with $C$. duneri.

\section{Chone dunerificta n. sp.} (Fig. 7)

Chone duneri. Giangrande, 1992: 525, Figs 15-16 (non Malmgren, 1867).

Material examined: Holotype, Paratypes (149) [MNCN 16.01/ 7369] 102 Gulf of Salerno, 1982, 5-15 m.

Non-type material: Tyrrhenian Sea [PC-ZL] 100 Brindisi, 1987, 10 m(6); 103 Gallipolli, 1982, -23 m (6); 105 bis Follonica 1982, 10 m (5); 105 Taranto 1995, -10 m (1); 105 Tris, Zoogli, 1993, -10 m(27). La Gomera, Canary Archipelago [DZUL] M3 P2, UTM 293720/3113675, 34 m, Coll. Tecnología Ambiental S.A, August 1995 (1). M7 P3, UTM 293140/31113800, medium sand, D50 medium, $0.25 \mathrm{~mm}$, Coll. Tecnología Ambiental S.A., August 1995 (5). M-125, UTM 272460/3105260, 25 m, Coll. Tecnología Ambiental S.A., August 1995 (3). M-134, UTM 272820/3104670, $25 \mathrm{~m}$, fine sand, D50 medium, $0.23 \mathrm{~mm}$, in Cymodocea nodosa prairies, Coll. Tecnología Ambiental S.A., August 1995 (1). M-144, UTM 284335/3101365, $30 \mathrm{~m}$, medium sand, D50 medium, $0.27 \mathrm{~mm}$, in Cymodocea nodosa prairies, Coll. Tecnología Ambiental S.A., August 1995 (1)

Additional material: Chone bimaculata Banse and Nichols, 1968, Paratypes [USNM 36280]. Chone collaris Langerhans, 1880, syntypes [NHMW 1966]. Chone duneri Malmgren, 1867, Topotypes [ZMUC POL-1755]. Chone longiseta Giangrande, 1992, Topotypes [PC-ZL, 142]. Chone veleronis Banse, 1972, Paratypes [LACM-AHF, POLY 0460].

\section{Description}

Colour, body shape and size: Body creamcoloured. Trunk cylindrical, posterior abdomen depressed dorso-ventrally (Fig. 7A). Body length: $6.5 \mathrm{~mm}$ (4.25-4.5), width: $0.75 \mathrm{~mm}$ (0.4-0.75). Tubes unknown.
Branchial lobes and branchial crown: Insertion of the branchial crown exposed beyond collar (Figs 7A-C, E-F). Branchial crown length: $3.5 \mathrm{~mm}$ (22.5). Radioles: 6 pairs (5-6). Pinnules equal size along radiole. Radiolar tips long (Figs 7D, G). The palmate membrane extends about three quarters of the branchial crown length. Lateral flanges $(f l)$ narrow (Fig. 7D). Dorsal lips triangular, elongated. Dorsal pinnular appendages: one pair short, united by a palmate membrane. Ventral lips rounded, small. Ventral radiolar appendages: 3 pairs, the basal one about one quarter of the branchial crown length, the middle one about one half, and the distal one about three quarters of the branchial crown length.

Peristomium: Anterior peristomial ring lobe (aprl) exposed beyond collar, distally bilobed (Figs 7A, C, E). Posterior peristomial ring collar: antero-dorsal (Fig. 7B), ventral and lateral margins entire (Figs 7E, C), ventral margin slightly higher then dorsal (Fig. 7A). Entire length of mid-dorsal collar margins forms a narrow gap. Dorsal pockets not developed. Ventral collar shield horseshoe-shaped, not swollen (Fig. 7C). Ratio of posterior peristomial ring collar length $v s$. chaetiger 2 length, in lateral view: 1:1.

Thorax: Chaetiger 1: two groups of elongate, narrowly hooded chaetae. Chaetigers 2 to 8 : Notopodia: superior group with two irregular rows of elongate narrowly hooded chaetae; inferior group with one anterior row of bayonet chaetae; two posterior rows with paleate chaetae with medium-sized mucro (Fig. 7H). Neuropodia: acicular uncini distributed as a regular row, main fang surmounted by four rows of teeth equal in size, occupying less than half of the main fang length (Fig. 7I).Glandular ridge on chaetiger 2 very narrow (Fig. 7A). Thoracic segments biannulate.

Abdomen: Abdominal segments: 29 (23-28). Anterior segments: two transverse rows of elongate, narrowly hooded chaetae, upper row chaetae half as long as lower row ones; uncini with the main fang surmounted by four rows of teeth equal in size, occupying less than half of the main fang length, main fang not extending beyond breast (Figs 7J-K). Posterior segments: very long, narrowly hooded chaetae, 25\% longer than those of anterior segments; modified uncini with the main fang surmounted by 6-7 regular vertical rows of equal in size teeth, occupying three quarters of the main fang length, main fang not extending beyond breast, breast rectangular (Figs 7L-M). Pygidium with a triangular posterior margin (Figs 7A, N). 


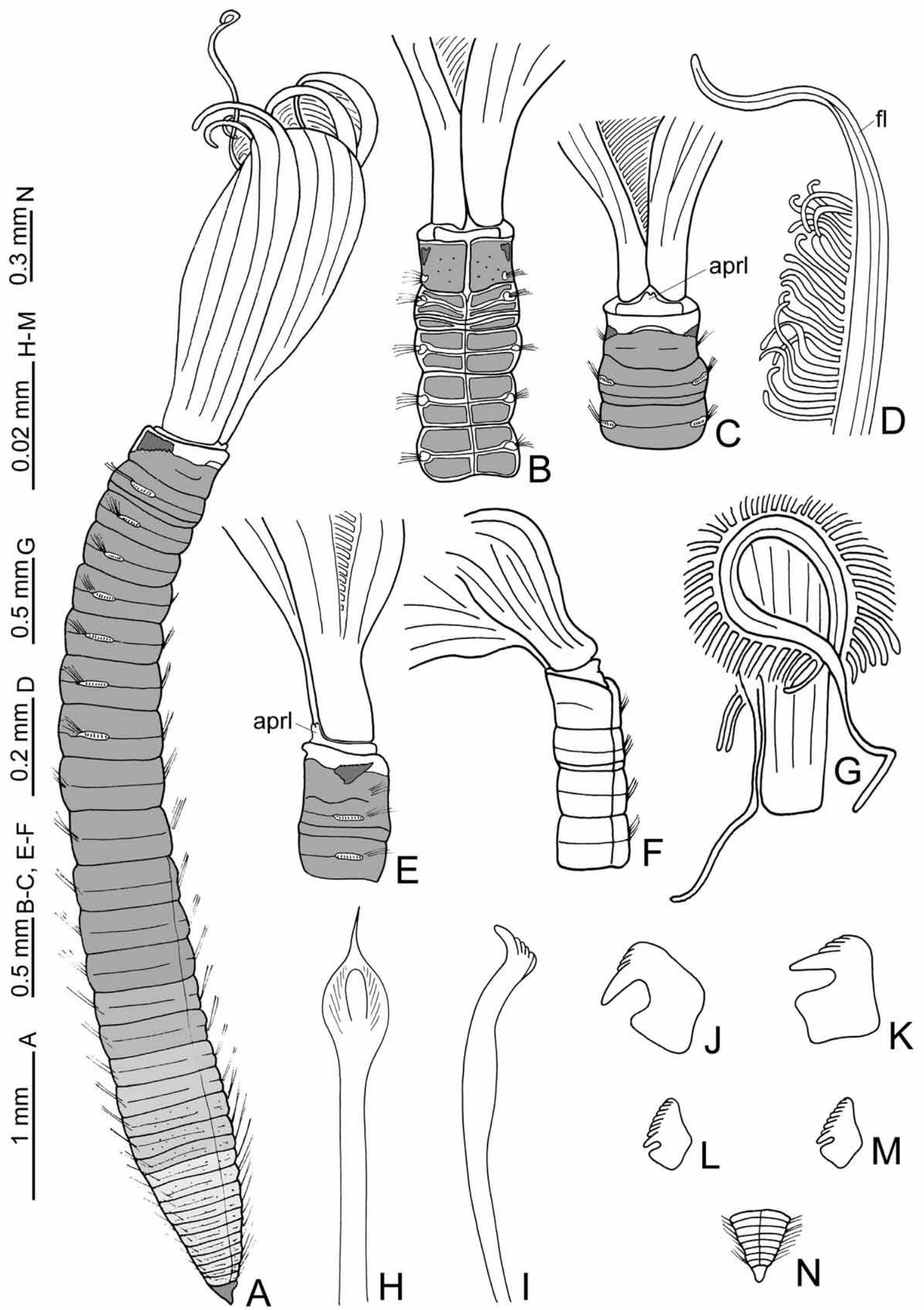

FIG. 7. - Chone dunerificta sp. nov. A, body, lateral view; B, anterior end, dorsal view; C, same, ventral view; D, radiolar tip; E-F, anterior end, lateral view; G, right, branchial lobe with radioles; H, paleate chaeta; I, thoracic uncinus; J-K, anterior abdominal uncini; L-M, posterior abdominal uncini; N, pygidium. A-C, E, methyl green staining pattern. A-E, H-M [Holotype, MNCN 16.01/7369], F-G, N [Paratype, MNCN]. Abbreviations: apr: anterior peristomial ring, aprl: anterior peristomial ring lobe, $f l$ : flange. 
Methyl green staining pattern: Thorax and abdomen stains uniformly, dorsal and ventrally (Figs 7A-C, E). Collar segment darker laterally (Figs 7B-C, E), the ventral collar shield and the anterior end of collar unstained. Abdominal posterior region with dark glandular spots.

Etymology: The specific name refers to the similarity between this species and Chone duneri. Derived from the Latin ficta, meaning false.

Remarks: Chone dunerificta n. sp. was identified in previous studies from the Mediterranean coasts as $C$. duneri based on the methyl green staining pattern and the very long radiolar tips. However, they differ because in Chone dunerificta n. sp. the dorsal lips are triangular, erect (broadly rounded, as long as wide in $C$.duneri); radiolar tips long (extra long in $C$. duneri), and posterior abdominal uncini modified (not modified in $C$. duneri). Chone dunerificta n. sp., $C$. collaris, $C$. longiseta, $C$. bimaculata and $C$. gambiae n. sp. have the anterior peristomial ring lobe bilobed and exposed beyond collar (Table 1). Chone dunerificta $\mathrm{n}$. sp., $C$. collaris, $C$. longiseta and $C$. bimaculata lacks a glandular ridge on chaetiger 9 (present in Chone gambiae n. sp.); C. collaris has the margin of collar crenulated (smooth in all others species); $C$. longiseta has ventral collar shield rectangular (horseshoe-shaped in C. dunerificta n. sp., C. collaris, C. longiseta and C. gambiae n. sp. while it is trapezoidal in C. bimaculata).

Distribution and habitat: eastern central Atlantic Ocean and Mediterranean Sea, on shallow sandybottoms.

Chone filicaudata Southern, 1914 (Fig. 8)

Chone filicaudata Southern, 1914: 141-143, Pl. 14-15, Figs 32A-L.

\section{Material examined}

Type material: Syntype [BMNH 1914.12.12.25] West Ireland, Coll. Dingle Bay, $32.18 \mathrm{~m}$, gravel.

\section{Description}

Colour, body shape and size: Body partially dehydrated, covered by sediment grains. Body length: $7 \mathrm{~mm}$, width: $0.5 \mathrm{~mm}$.

Branchial lobes and branchial crown: Insertion of the branchial lobes not exposed beyond collar. Branchial crown length: $3.5 \mathrm{~mm}$. Radioles: 8 pairs.

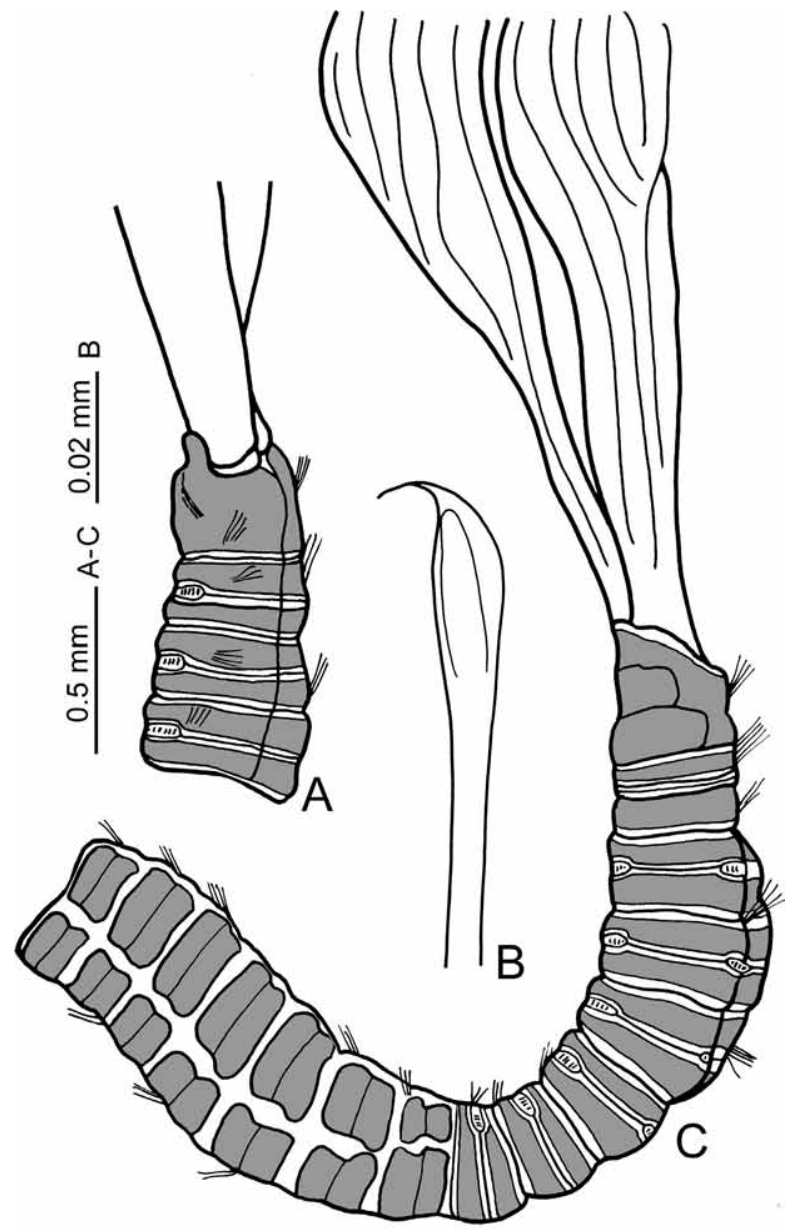

FIG. 8. - Chone filicaudata. A, Anterior end, lateral view; B, paleate chaeta; C, anterior end, ventro-lateral view. A, C, methyl green staining pattern. A-C [Syntype, BMNH 1914.12.12.25].

Radioles with all pinnules long. Radiolar tips medium to long. Palmate membrane extends about three quarters of the branchial crown length. Lateral flanges broad. Dorsal lips broad at the base elongate towards the tip. Ventral lips rounded, small, one quarter of the dorsal lips length. Ventral radiolar appendages: 6 pairs.

Peristomium: Anterior peristomial ring lobe exposed beyond collar, distally bilobed. Posterior peristomial ring collar: antero-dorsal, ventral and lateral margins entire, ventral margin slightly higher than dorsal; entire length of mid-dorsal collar margins forms a narrow gap. Ventral collar shield swollen, trapezoidal-shaped, two times wider than long. Ratio of posterior peristomial ring collar length $v s$. chaetiger 2 length, in lateral view: 1:1.

Thorax: Chaetiger 1: two groups of elongate, narrowly hooded chaetae. Chaetigers 2 to 8 : Notopodia: superior group with two irregular rows of elongate narrowly hooded chaetae; inferior group 
with one anterior row of bayonet chaetae; two posterior rows with paleate chaetae with short mucro (Fig. 8B). Neuropodia: acicular uncini distributed as a regular row, main fang surmounted by four rows of teeth, second tooth enlarged, located offset midline, dentition occupying less than three quarters of the main fang length. Glandular ridge on chaetiger 2 narrow. Thoracic segments biannulate. Pre- and post-chaetal lobes well developed.

Abdomen: Abdominal segments: 18. Anterior segments: two transverse rows of elongate, narrowly hooded chaetae, upper row chaetae half as long as lower row ones; uncini with the main fang surmounted by four rows of teeth, second tooth enlarged, dentition occupying less than half of the main fang length, main fang not extending beyond breast. Posterior segments: very long, narrowly hooded chaetae; modified uncini with the main fang surmounted by 6-7 regular vertical rows of teeth equal in size, occupying three quarters of the main fang length, main fang not extending beyond breast, breast rectangular. Pygidium with triangular posterior margin, pygidial cirrus broken.

Gametes: Not observed.

Methyl green staining pattern: The epidermis is completely glandular, stains uniformly in thorax and abdomen, dorsal, ventral and laterally (Figs 8A, C).

Remarks: Until recently, Chone filicaudata has been the only widely-known Chone member possessing a pygidial cirrus, such that findings of any Chone specimen with pygidial cirrus were inevitably recorded as $C$. filicaudata (Cochrane, 2000). However, there are more species sharing this feature. Thus, Chone filicaudata has been highly recorded from the Mediterranean Sea (Bellan, 1964; Harmelin, 1969; Amoureux, 1976; Drago et al. 1978; Farina et al. 1985; Giangrande, 1992). However, none of the authors illustrated their specimens, or described them in detail, except for the last one, and her records for the Mediterranean Sea do not correspond with the type material of $C$. filicaudata: her specimens have the anterior peristomial ring lobe entire, triangular (bilobed in C. filicaudata); radiolar tips medium-length (short in C. filicaudata); radiolar flanges broad (narrow in C. filicaudata); the dorsal methyl green staining pattern is less coloured than ventral (stained uniformly dorsal and ventrally in C. filicaudata).

Southern (1914) illustrated the paleate chaetae in two different views (Fig. 32F), the first one is a narrower, bilaterally swollen form, the second one shows a well developed palea, but this relative shape depends on the angle in which chaetae are seen. The examination of type material confirms that $C$. filicaudata has well-developed, paleate chaeta.

\section{Distribution: North Atlantic Ocean.}

\section{Chone gambiae n. sp.}

(Fig. 9)

Material examined

Type material: Holotype, Paratype [MNCN 16.01/7366] Napoli, Castel dell'Ovo, $40^{\circ} 49.43^{\prime} \mathrm{N}, 14^{\circ} 14.35 \mathrm{E}$, February 2004, $-7 \mathrm{~m}$.

Additional material: Chone americana Day, 1973, Paratypes [USNM 43137]. Chone filicaudata Southern, 1914, Syntype [BMNH 1914.12.12.25]. Chone veleronis Banse, 1972, Paratypes [LACM-AHF POLY 0460].

\section{Description}

Colour, body shape and size: Body creamcoloured. Trunk cylindrical, posterior abdomen depressed dorso-ventrally. Body length: $7 \mathrm{~mm}$ (6.5), width: $0.5 \mathrm{~mm}(0.5)$.

Branchial lobes and branchial crown: Insertion of the branchial lobes exposed beyond collar (Fig. 9A). Branchial crown length: $3 \mathrm{~mm}$ (2.5). Radioles: 3 pairs (3). Pinnules equal size along radiole. Radiolar tips filiform, long (Fig. 9C). The palmate membrane extends up to three quarters of the branchial crown length. Lateral flanges very narrow. Dorsal lips triangular, erect. Dorsal pinnular appendages: one short pair united by a palmate membrane. Ventral lips small, rounded, small. Ventral radiolar appendages: one pair, extending one half of the branchial crown length.

Peristomium: Anterior peristomial ring lobe exposed beyond collar, distally bilobed (Fig. 9D). Posterior peristomial ring collar: antero-dorsal ventral and lateral margins entire, ventral margin slightly higher than dorsal; entire length of mid-dorsal collar margins forms a narrow gap. Dorsal pockets not developed. Ventral collar shield horseshoeshaped, not well delimited (Fig. 9D). Ratio of posterior peristomial ring collar length $v s$. chaetiger 2 length, in lateral view: 1.5:1.

Thorax: Chaetiger 1: two groups of elongate, narrowly hooded chaetae. Chaetigers 2 to 8: Notopodia: superior group with two irregular rows of elongate, narrowly hooded chaetae (Fig. 9H); inferior group with one anterior row of bayonet chaetae (Fig. 9J); two posterior rows with paleate chaeta with short mucro (Fig. 9I). Neuropodia: acicular uncini distributed as a regular row, main fang 


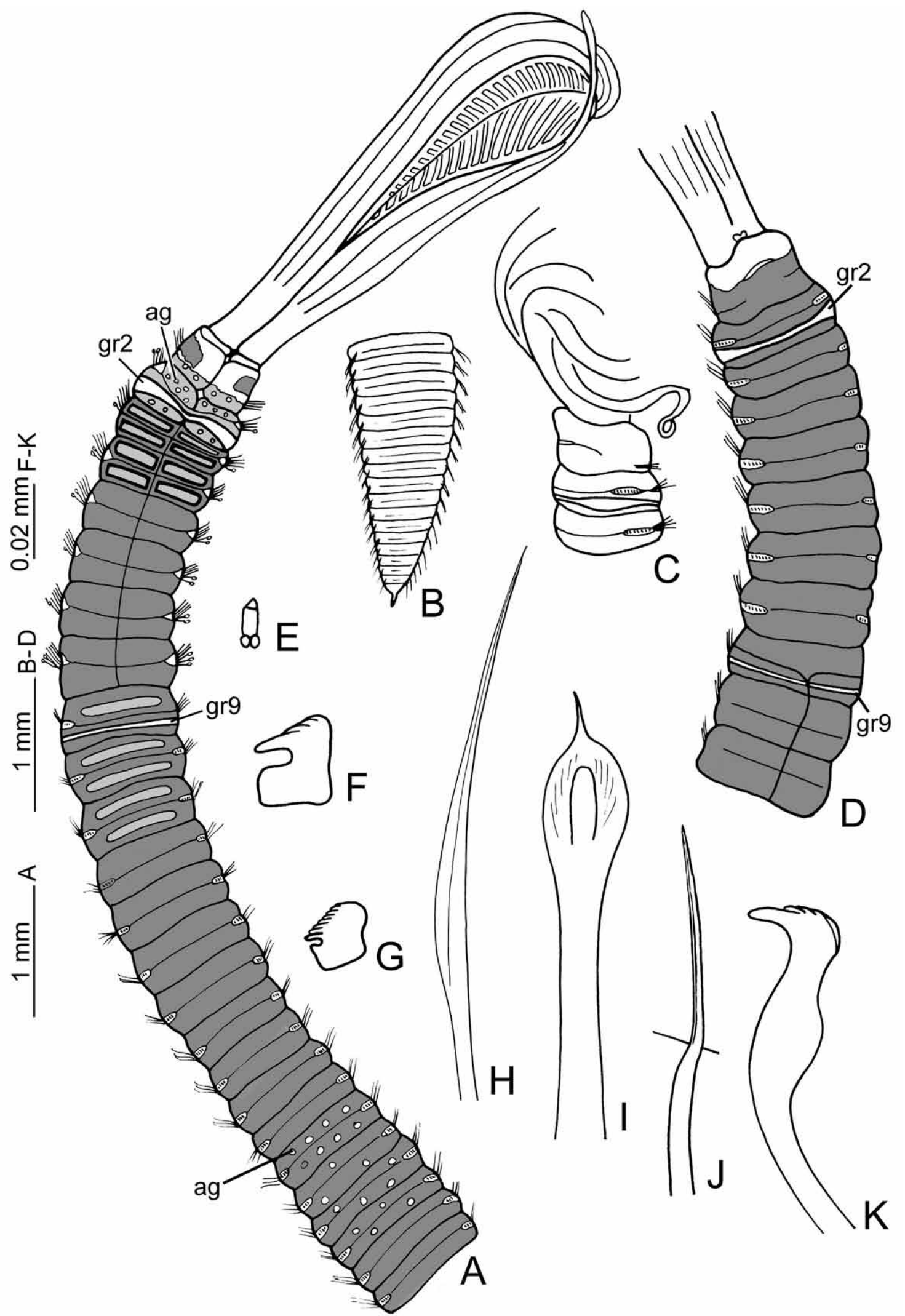

FIG. 9. - Chone gambiae sp. nov. A, body, dorsal view; B, posterior abdomen; C, anterior end, lateral view; D, same, ventral view; E, spermatozoon; F, anterior abdominal uncinus; G, posterior abdominal uncinus; $\mathrm{H}$, elongate, thoracic narrowly hooded chaeta; I, paleate chaeta; $\mathrm{J}$, bayonet chaeta; $\mathrm{K}$, thoracic uncinus. A, D, methyl green staining pattern. A-K [Holotype, MNCN 16.01/7366]. Abbreviations: ag: acidophil glands, gr2: glandular ridge on chaetiger 2, gr9: glandular ridge on chaetiger 9. 
surmounted by four rows of teeth equal in size, occupying less than half of the main fang length (Fig. 9K). Glandular ridge on chaetiger 2 (gr2) broad laterally (Figs 9A, C-D). Thoracic segments biannulate.

Abdomen: Abdominal segments: 42. Narrow, glandular ridge on segment 9 (gr9) (Figs 9A, D). Anterior segments: two transverse rows of elongate, narrowly hooded chaetae, upper row chaetae half as long as lower row ones; uncini with the main fang surmounted by four rows of teeth equal in size, occupying less than half of the main fang length, main fang not extending beyond breast (Fig. 9F). Posterior segments: very long, narrowly hooded chaetae, $25 \%$ longer than those of anterior segments; modified uncini with the main fang surmounted by 6-7 regular vertical rows of equal in size teeth, occupying three quarters of the main fang length, main fang not extending beyond breast, breast rectangular (Fig. 9G). Pygidium with triangular posterior margin and short cirrus (Fig. 9B).

Gametes: Spermatozoa with barrel-shaped nucleus, triangular acrosome and two rounded mitochondria (Fig. 9E).

Methyl green staining pattern: After staining the dorsal epidermis have large, rounded, white spots on thoracic segments (acidophil glands, $\boldsymbol{a g}$ ). The collar segment has lateral dark spots dorsally; ventrally it stains only in the basal half. The thoracic and abdominal segments stains as rectangles, only the margins are coloured, and white bands are visible (Figs 9A, D).

Etymology: This species is named in honour of Dr. Maria Cristina Gambi (Zoological Station of Naples, Italy), who collected the materials and kindly sent them to us for their study.

Remarks: Chone gambiae n. sp. is unique in having large acidophil glands on the epidermis, its glandular ridge on chaetiger 2 is broad laterally, and a glandular ridge is present on chaetiger 9 . The presence of the glandular ridge on chaetiger 2 is one of the diagnostic characters for "Chonea" (Chone, Euchone and Jasmineira) according to Cochrane (2003); the presence of glandular ridges on abdominal segments has only been recorded in C. veleronis, and this property are also shared with some small species of Euchone (Banse, 1970).

Chone americana, $C$. filicaudata and $C$. gambiae n. sp., have pygidial cirrus. Chone filicaudata and $C$. gambiae n. sp., have the anterior peristomial ring lobe incised, whereas it is intact in C. americana. The glandular ridge on chaetiger 2 is narrow in $C$. filicaudata, but laterally broad in C. gambiae n. sp. In Chone gambiae n. sp., $C$. dunerificta n. sp., $C$. collaris and $C$. longiseta, the anterior peristomial ring lobe is bilobed and exposed beyond collar (Table 1); however, the margin of the collar is crenulated in $C$. collaris (smooth in others). In Chone gambiae n. sp., the glandular ridge on chaetiger 2 is broad laterally (narrow in $C$. dunerificta n. sp., and C. longiseta), and an additional glandular ridge is present on chaetiger 9 (absent in C. dunerificta $\mathrm{n}$. sp., and C. longiseta).

Distribution and habitat: Gulf of Naples, Italy, sandy bottom.

Chone longiseta Giangrande, 1992

(Fig. 10)

Chone longiseta Giangrande, 1992: 519-521, Figs 3-5.

Material examined: Tyrrhenian Sea [PC-ZL] 140 Foce di Tevere 1980,-15 m (9), 141 Gallipoli, 1982, -15 m (7), 142 Salerno, 1982 -10 m (6), 143 Gulf of Policastro 1983, -28 m (10), 144 Coste Laziali, 1993, -19 m (2).

\section{Additions to the description}

Colour, body shape and size: Trunk cylindrical, posterior abdomen depressed dorso-ventrally. Body length: $6-8 \mathrm{~mm}$, width: $0.4 \mathrm{~mm}$. Tubes unknown.

Branchial lobes and branchial crown: Insertion of the branchial crown exposed beyond collar dorsally. Branchial crown length: $2.5 \mathrm{~mm}$. Radioles: 6 pairs. Radiolar tips extra long (Figs 10A, D). The palmate membrane extends up a half of the branchial crown length. Lateral flanges broad. Dorsal lips triangular, long. Ventral radiolar appendages: 3 pairs.

Peristomium: Anterior peristomial ring lobe (aprl) exposed beyond collar, distally bilobed (Fig. 10C). Posterior peristomial ring collar: dorsal, ventral and lateral margins entire, ventral margin of the same height as dorsal; entire length of mid-dorsal collar margins forms a narrow gap (Fig. 10D). Dorsal pockets well developed. Ventral collar shield rectangular (Fig. 10C). Ratio of posterior peristomial ring collar length $v s$. chaetiger 2 length, in lateral view: 1.5:1.

Thorax: Paleate chaetae with short mucro (Fig. 10B). Teeth of uncini equal in size. Glandular ridge on chaetiger 2 very narrow. Thoracic segments biannulate. 

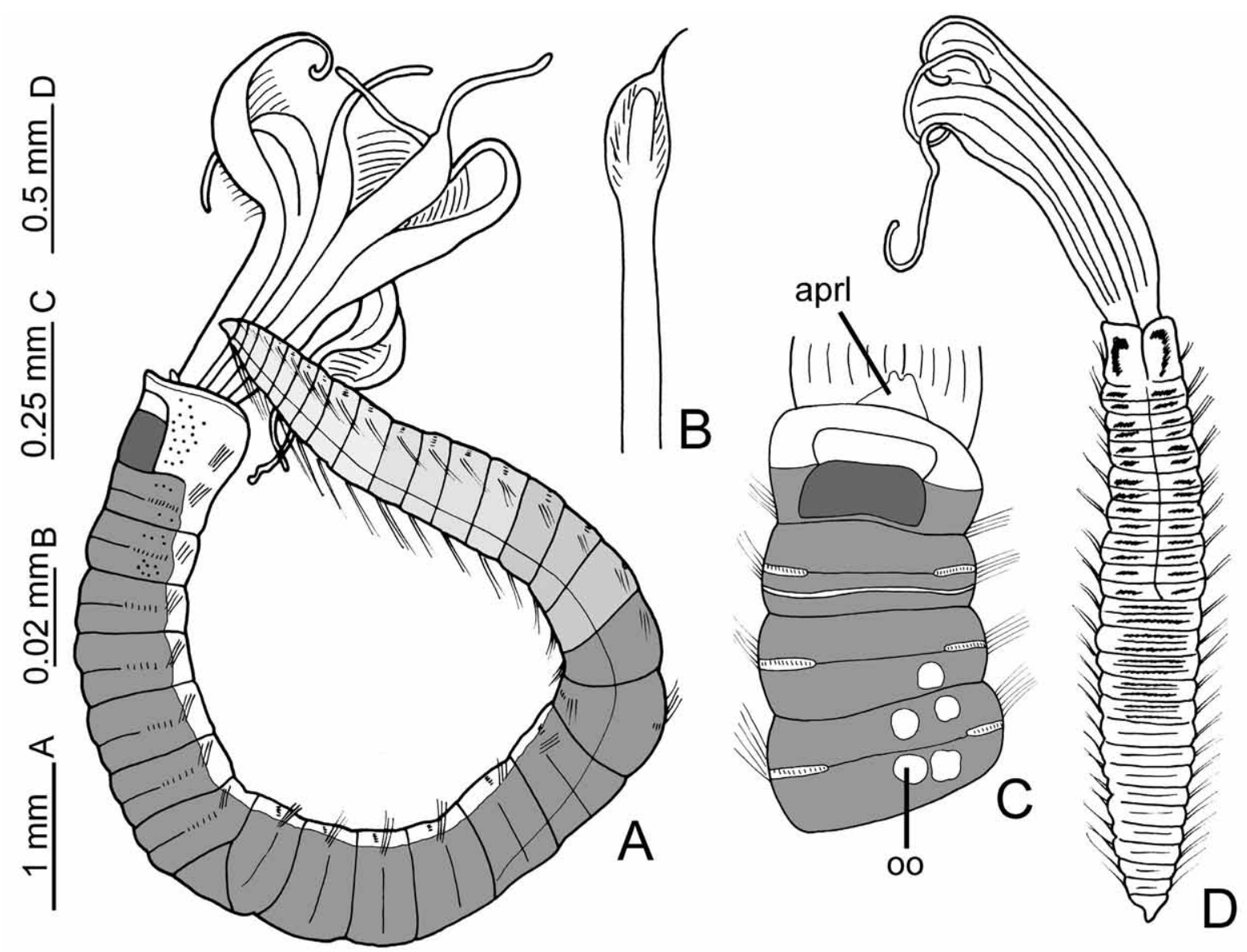

FIG. 10. - Chone longiseta. A, body, lateral view; B, paleate chaeta; C, anterior end, ventral view; D, body, dorsal view. A, C, methyl green staining pattern. A-D [PC-ZL 140, Foce di Tevere]. Abbreviations: aprl: anterior peristomial ring lobe, oo: oocytes.

Abdomen: Abdominal segments: 18-26. Teeth of uncini equal in size. Pygidium with triangular posterior margin (Figs 10A, D).

Gametes: Female with oocytes (oo) in thorax (Fig. 10C).

Methyl green staining pattern: The basal half of the collar ventral stains uniformly, the distal half is not coloured (Figs 10A, C). Ventrally, body stains uniformly (Fig. 10C). Dorsally segments are slightly coloured (Fig. 10D). The posterior abdomen is less coulored than the body anterior end (Fig. 10A). Laterally, there is no colour (Fig. 10A).

Remarks: Chone longiseta was described as lacking paleate chaetae, a generic character for Chone Krøyer, 1856 (Tovar-Hernández and SosaRodríguez, 2006); however, re-examination of specimens recorded by Giangrande (1992) confirms the presence of paleate chaetae with short mucro (Fig. $10 \mathrm{~B})$; most are broken and only the shaft is preserved. The additions to the original description of $C$. longiseta are the following: paleate chaetae with short mucro; anterior peristomial ring lobe exposed beyond collar, bilobed; flanges broad; posterior abdominal uncini modified as Amphicorina-shape; and posterior abdomen depressed dorso-ventrally. Chone longiseta have the ventral collar shield rectangular (rounded, reminiscent, not easy discernible in C. acustica, horseshoe-shaped in C. arenicola, $C$. collaris, C. usticensis, C. gambiae n. sp., and $C$. dunerificta $\mathrm{n}$. sp.) (Table 1).

Distribution and habitat: Mediterranean Sea, on muddy sand bottoms with algal detritus.

\section{Chone usticensis Giangrande, Licciano and Castriota, 2006}

(Fig. 11)

Chone usticensis Giangrande et al. 2006: 53-57, Figs 2-4.

Material examined: Southern Tyrrhenian Sea [PC-ZL 167] Ustica Island (5). Gulf of Naples [LEB] Portici, $40^{\circ} 49^{\prime} \mathrm{N}$, $14^{\circ} 19.28^{\prime} \mathrm{E}, 2002$, -9 m (10); Portici, 4049'N, 14\%19.28' $\mathrm{E}$, February 2004, -11 m (3); Napoli, Castel dell'Ovo, 2003 (8); 
Napoli, Castel dell'Ovo, 4049.43'N, 14¹4 35'E, February 2004, 7 m (2). La Gomera, Canary Archipelago [DZUL] M2 P1, UTM 293650/3113600, $20 \mathrm{~m}$, medium sand, D50 medium, $0.25 \mathrm{~mm}$, Coll. Tecnología Ambiental S.A, August 1995 (7); M2 P2 (4). M152, UTM 272820/3104670, $25 \mathrm{~m}$, fine sand, D50 medium, 0.23 $\mathrm{mm}$, in Cymodocea nodosa prairies, Coll. Tecnología Ambiental S.A., August 1995 (1).

Methyl green staining pattern: The basal half of the collar and the basal half of the ventral collar shield stain uniformly; the distal half is not coloured (Fig. 11A). Dorsally, the collar segment has two dark spots in both corners, with dark glandular spots (Fig. 11B). Thoracic and abdominal segments stain uniformly (Fig. 11B). The pigment along the posterior end of the body is quickly lost.

Remarks: Chone usticensis, C. acustica and $C$. longiseta have extra long radiolar tips (Table 1). Chone acustica and $C$. usticensis have narrow radiolar flanges and the anterior peristomial ring lobe is triangular, not exposed beyond collar. For contrast, C. longiseta have broad flanges and anterior periostomial ring lobe bilobed, exposed beyond collar. The dorsal lips in $C$. acustica are extra long, 10 times longer than wide (three times longer than wide in $C$. longiseta).

Distribution and habitat: Mediterranean Sea, on mixed soft bottom with rhodoliths presents (Giangrande et al. 2006).

\section{DISCUSSION}

The present redescription of $C$. acustica allows us to consider the species as having the palmate membrane. This species was originally described as Dialychone due to the absence of palmate membrane by Claparède (1870), confirmed by Iroso (1921). Later, Knight-Jones et al. (1991) and Giangrande (1992) placed the taxon within Chone by observing a very low palmate membrane extending for about a quarter of the branchial crown length. Chone acusti$c a$ was the first species in which the modified, posterior abdominal uncini (as rasp-shaped plates or Amphicorina-type) were found; however, although Claparède (1870), Iroso (1921) and LoBianco (1893) referred to the presence of Amphicorina type uncini in the abdomen, none of them mentioned the presence of inter-segmental variation of uncinal type. Considering also the structure of dorsal lips contrasting with the rounded one found in the type species $C$.
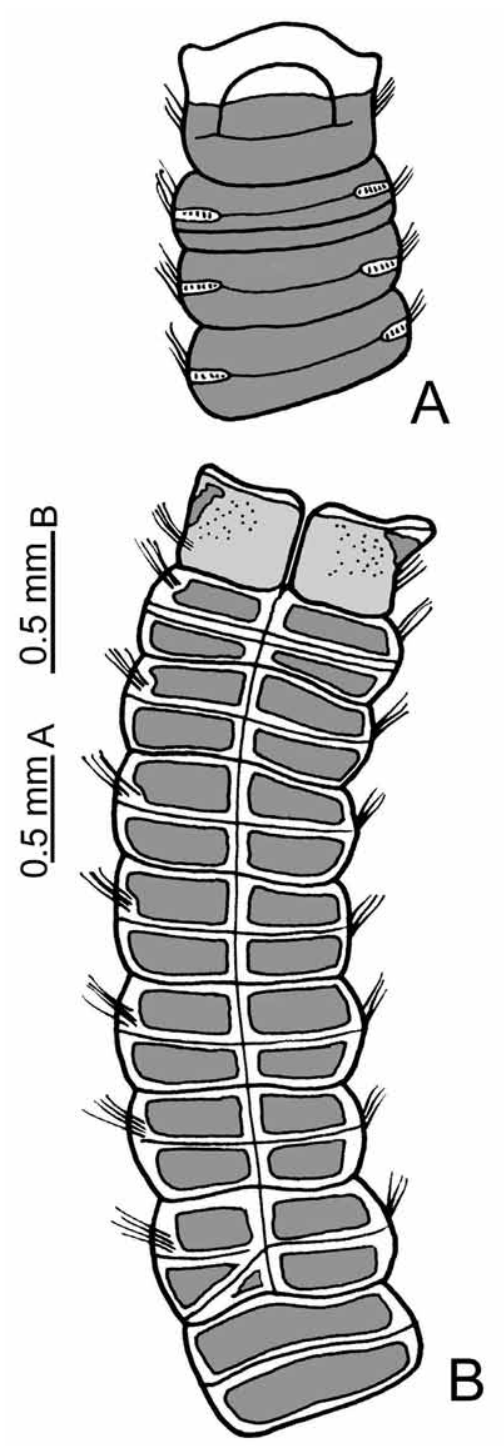

FIG. 11. - Chone usticensis, methyl green staining pattern. A) Anterior end, ventral view, B) same, dorsal view. A-B [PC-ZL 167 Ustica island].

infundibuliformis, it is possible that $C$. acustica really belongs to a different genus.

It is interesting that inter-segmental variation of abdominal uncini and elongated dorsal lips are features present in all the Mediterranean taxa. Amphicorina-type uncini in C. acustica, C. arenicola, C. collaris, C. longiseta and C. usticensis are located in the segments of the posterior abdominal dorso-ventral depression. Although the posterior depression in these Chone species is different to the anal depression in Euchone, in both genera the Amphicorina-type abdominal uncini are located in the posterior modified area of abdomen.

The type species $C$. infundibuliformis lacks the dorso-ventral depression on the posterior abdomen, 
the uncini are similar along the abdomen, and the dorsal lips are broadly rounded, vascularised by a plexus of few and small blood vessels, unlike those in C. acustica, C. arenicola, C. collaris, C. longiset $a$ and $C$. usticensis (among others). These features could be enough to split the genus, but they must be thoroughly reviewed in all these species and taken in consideration in further studies to evaluate the phylogeny of Chone. However, based on the assessment of morphological characters, we recognise a subgroup of Chone which all are recorded from the Mediterranean Sea and the eastern central Atlantic.

The redescription of Mediterranean taxa in the present paper indicated that $C$. arenicola is characterised by: 1) large, lateral, irregular purple spots on the radiolar axis skeleton, on flanges (not in the rachis), 2) branchial lobes exposed beyond collar, 3) anterior peristomial ring lobe exposed beyond collar, and 4) posterior abdominal uncini modified. Chone collaris is unique among Chone species in having the margin of the collar crenulated. Chone longiseta, contrasting the original description, has the presence of paleate chaetae with short mucro; anterior peristomial ring lobe exposed beyond collar, bilobed; and modified, posterior abdominal uncini. The unique distinguishing features for the new species here reported, Chone gambiae n. sp., described from the Gulf of Naples, is the glandular ridge on chaetiger 2 broad laterally, and a narrow glandular ridge on chaetiger 9; lastly, Chone dunerificta n. sp., described from the Gulf of Salerno, is unique in having: long radiolar tips; anterior peristomial ring lobe exposed beyond collar, bilobed; branchial lobes exposed beyond collar and modified, posterior abdominal uncini. This last taxon is probably the most widely distributed within the Mediterranean Sea but is wrongly identified as $C$. duneri. Chone duneri is restricted to the Arctic Ocean and the records of $C$. filicaudata from the Mediterranean Sea are erroneous, as the species is distributed in the North Sea.

\section{ACKNOWLEDGEMENTS}

We gratefully acknowledge helpful comments on the manuscript by Sabine Cochrane (AkvaplanNiva, Polar Environment Centre, Troms $\varnothing$ ) and Greg Rouse (SCRIPPS). We wish to extend special thanks to Jorge Núñez (DZUL), who made an intense search of sabellids in his collections from Madeira and provided useful materials and additional information. Emma Sherlock (BMNH), Sandra Farrington (FSBC), Leslie Harris (LACM-AHF), Maria Cristina Gambi (LEB), Ardis Johnston (MCZ), Helmut Sattmann (NHMW), Andy Mackie and Teresa Darbyshire (NMW); Karin Sindemark $(\mathrm{SMNH})$, Kristian Fauchald and William Keel (USNM), Erik Lazo-Wasem (YPM) and Danny Eibye-Jacobsen (ZMUC), arranged loans of museum material and other collection information. This work was possible thanks to the guidance and support of Sergio I. Salazar-Vallejo (ECOSUR) and Kirk Fitzhugh (LACM-AHF). Luis F. Carrera-Parra (ECOSUR) reviewed the manuscript and gave valuable recommendations. The first author (MAT-H) received financial support from El Colegio de la Frontera Sur, Chetumal (México) for a research visit to the University of Lecce (Italy), and a scholarship from El Consejo Nacional de Ciencia y Tecnología (CONACyT) for her Ph.D studies.

\section{REFERENCES}

Albertelli, G., M. Cattaneo, N. Della Croce and N. Drago. - 1981. Benthos della piattaforma continentale Ligure. Alassio, Savona, Chiavari, Coniglia (1977-1981). Università degli Studi di Genova, Istituto di Scienze Ambientali Marine, Cattedra di Idrobiologia e Pescicoltura, Rapporto Tecnico 14.

Albertelli, G., M. Cattaneo, N. Della Croce and N. Drago. - 1983. Macrobenthos delle isole di Capraia, Pianosa, Giglio, Montecristo, Giannutri, Elba (Arcipelago Toscano). Università degli Studi di Genova, Istituto di Scienze Ambientali Marine, Cattedra di Idrobiologia e Pescicoltura, Rapporto Tecnico 18.

Banse, K. - 1970. The small species of Euchone Malmgren (Sabellidae, Polychaeta). Proc. Biol. Soc. Wash., 83, 387-408.

Banse, K. - 1972. Redescription of some species of Chone Kröyer and Euchone Malmgren, and three new species (Sabellidae, Polychaeta). Fish. Bull. Wildlife Serv. US Dep. Int., 70: 459-495.

Banse, K. and F.H. Nichols. - 1968. Two new species and three new records of benthic polychaetes from Puget Sound (Washington). Proc. Biol. Soc. Wash., 81: 223-230.

Bedulli, D. C.N. Bianchi, G. Zurlin and C. Morri. - 1986. Caratterizzazione biocenotica e strutturale del macrobenthos delle coste pugliesi. In: Indagine ambientale del sistema marino costiero della regione Puglia, pp. 227-255. E.N.E.A.C.R.E.A. Santa Teresa-La Spezia.

Bush, K.J. - 1904. On Spirorbis from Japan. In: J.P. Moore (ed.), Report on Sabellidae and Serpulidae. Proc. Acad. Nat. Sci. Philadelphia, 56: 175.

Castelli, A. - 1982. Distriobuzione dei Policheti alla foce dell'arno. Atti Soc. Nat. Mat. Modena, 113: 53-66.

Claparède, E. - 1870. Les annélides chétopodes du Golfe de Naples, Supplément. Mém. Soc. Phys. Hist. Nat. Genève, 20(2): 365-542.

Cochrane, S.J. - 2000. Taxonomy and systematics of selected marine soft-bottom fan worms (Polychaeta: Sabellidae: Sabellinae). Ph.D thesis, Univ. Saint Andrews, Scotland.

Cochrane, S.J. - 2003. Snowflakes and feather-dusters - some challenges for soft-bottom fanworm systematics. Hydrobiologia, 496: 49-62.

Cognetti Varriale, A.M. and R. Zunarelli Vandini. - 1978. Distribution des Polychètes sur le fonds meubles infralittoraux du Molise (Adriatique). Cah. Biol. Mar., 19: 37-45.

Day J.H. - 1973. New Polychaeta from Beaufort, with a key to all 
species recorded from North Carolina. National Oceanographic and Atmospheric Agency, Tech. Rep., National Marine Fisheries Service, Circular, 375: 153.

Drago, N. and G. Alberelli. - 1978. Étude faunistique et bionomique du littoral de Cogoleto (Golfe de Genes). Tethys, 8 (2): 203-212.

Eliason, A. - 1962. Undersökningar över Öresund, 41. Weitere Untersuchungen über die Polychaetenfauna des Öresunds. Acta Universitatis Lundensis, 58(9): 1-98.

Farina R., A. Castelli and C. Lardicci. - 1985. Distribuzione dei policheti sui fondi mobili infralittorali della costa meridionale dell' isola d'Elba (Arcipelago Toscano). Atti del Seminario Matematico e Fisico dell' Università di Modena, 116: 25-34.

Fitzhugh, K. - 1989. A systematic revision of the Sabellidae-Caobangiidae-Sabellongidae complex (Annelida: Polychaeta). Bull. Am. Mus. Nat. His., 192: 104.

Giangrande, A. - 1992. The genus Chone (Polychaeta, Sabellidae) in the Mediterranean Sea with description of C. longiseta n. sp. Boll. Zool., 59: 517-529.

Giangrande, A. - 1989. Censimento dei policheti dei mari italiani: Sabellidae Malmgren, 1867. Atti. Soc. Tosc. Sci. Nat., Mem., Serie B, 96: 153-189.

Giangrande, A., M. Licciano and L. Castriota. - 2006. Description of Chone usticensis sp. nov. (Polychaeta, Sabellidae) from the Mediterranean Sea. Zootaxa, 1168: 51-58.

Hartmann-Schröder, G. - 1971. Annelida, Borstenwürmer, Polychaeta. In: Dahl, Maria and Peus, Fritz. Tierwelt Deutschlands und der angrenzenden Meeresteile nach ihren Maermalen und nach ihrer Lebensweise, pp. 1-594. Gustav Fischer Verlag, Jena.

Hofsommer, A. - 1913. Die Sabelliden-Ausbeute der 'Poseidon'Fahrten und die Sabelliden der Kieler Bucht. Wiss. Meeresunters. Kiel, 15: 305-364.

International Commission on Zoological Nomenclature. - 2000. International Code of Zoological Nomenclature, 4 edition. The International Trust for Zoological Nomenclature, London.

Iroso, I. - 1921. Revisione dei Serpulidi e Sabellidi del Golfo di Napoli. Pubbl. Staz. Zool. Napoli, 3: 68-85.

Jiménez-Cueto, M.S. and S.I. Salazar-Vallejo. - 1991 (1990). Anélidos poliquetos de la Reserva de la Biosfera de Sian Ka'an. In: D. Navarro and J.G. Robinson (eds.), Diversidad Biológica en la Reserva de Sian Ka'an, Quintana Roo, pp. 147-150, México. CIQROO (Chetumal), PSTC (University of Florida).

Johnson, H.P. - 1901. The Polychaeta of the Puget Sound region. Proc. Boston Soc. Nat. Hist. 29(18): 381-437.

Katzman, W. - 1973. Contributo alla conoscenza dei Policheti del mare Adriatico (Medio Adriatico-fondi mobili tra 10 e $230 \mathrm{~m}$ di profondità). Quad. Lab. Tecnol. Pesca, 1 (5): 143-155.

Katzman, W. - 1982. Bemerkungen zur Systematik Omologie und Tiergeographie den Mitteladriatichen Weichbodenpolycheeten. Ann. Naturhistor. Mus. Wien, 84b: 2-36.

Kinberg, J.G.H. - 1867. Annulata nova. Öfver. K. Vetenskapsakad. Förh. Stockh., 23(9): 337-357.

Kirkegaard, J.B. - 1996. Havbørsteorme II, Sedentaria. Vinderup Bogtrykkeri A/S, Vinderup.

Knight-Jones, P., W. Knight-Jones and Z. Ergen. - 1991. Sabelliform polychaetes, mostly from Turkey's Aegean coast. J. Nat. Hist., 25: 837-858.
Krøyer, H. - 1856. Bidrag til Kundskab af Sabellerne. K. Danske Vidensk. Selskabs Forhandlinger, 1-36.

Langerhans, P. - 1880. Die wurmfauna Madeiras, 2. Z. W. Zool., 33 (1-2): 271-316.

Latreille, P.A. - 1825. Familles Naturelles du Règne Animal exposées succinctement et dans un Ordre analytique avec l'indication de leurs genres etc. Baillière JB, Paris.

Lo Bianco, S. - 1893. Anellidi tubicoli del Golfo di Napoli. Atti Accad. Sci. Fis. Mat. Napoli, 5: 65-81

Malmgren, A.J. - 1867. Annulata Polychaeta Spetsbergiae, Groenlandiae, Islandiae et Scandinaviae hactenus cognita. Öfver. K. Vetenskapsakad. Förh. Stockh., 24(4): 127-235.

Moore, J.P. - 1906. Descriptions of two new Polychaeta from Alaska. Proc. Acad. Nat. Sci. Philadelphia, 1906: 352-355.

Moore, J.P. - 1923. The polychaetous annelids dredged by the U.S.S. 'Albatross' off the coast of southern California in 1904, 4. Spionidae to Sabellariidae. Proc. Acad. Nat. Sci. Philadelphia, 75: 179-259.

Perkins, T.H. and T. Savage. - 1975. A bibliography and checklist of polychaetous annelids of Florida, the Gulf of Mexico and the Caribbean Region. Flor. Mar. Res. Pub., 14: 1-62.

Pettibone, M. - 1954. Marine polychaete worms from Point Barrow, Alaska, with additional records from the North Atlantic and North Pacific. Proc. US Nat. Mus., 103(3324): 203-356.

Rouse, G.W. - 1994. New species of Oriopsis Caullery and Mesnil from Florida, Belize and Aldabra Atoll (Seychelles), and a new species of Amphiglena Claparède from Seychelles (Polychaeta: Sabellidae: Sabellinae). Bull. Mar. Sci., 54(1): 180-202.

Rullier, F. and L. Amoureux. - 1968. Annélides Polychètes du Golfe de Tarente. Résultats des campagnes de l'Albatros (19661967). Ann. Mus. Civ. Stor. Nat. Giacomo Doria, Genova, 77: 386-407.

Southern, R. - 1914. Clare Island Survey: Archiannelida and Polychaeta. Proc. Roy. Irish Acad., 31(47): 1-160.

Tovar-Hernández, M.A. - 2005. Redescription of Chone americana Day, 1973 (Polychaeta: Sabellidae) and description of five new species from the Grand Caribbean Region. Zootaxa, 1070: 1-30.

Tovar-Hernández, M.A. and T. Sosa-Ramírez. - 2006. Redescription of Chone infundibuliformis Krøyer, 1856 (Polychaeta: Sabellidae) and histology of the branchial crown appendages, collar and glandular ridge. Zootaxa, 1115: 31-59.

Tovar-Hernández, M.A. (in press). Revision of Chone Krøyer, 1856 (Polychaeta: Sabellidae) from North America and descriptions of four new species. J. Nat. Hist.

Vatova, A. - 1949. La fauna bentonica dell'alto e medio Adriatico. Nova Thalassia, 1(3): 1-110.

Verrill, A.E. - 1885. Notice of recent additions to the marine Invertebrata of the northeastern coast of America, with descriptions of new genera and species and critical remarks on others, 5. Annelida, Echinodermata, Hydroida, Tunicata. Proc. US Nat. Mus., 8(27): 424-448.

Wessenberg-Lund, E. - 1950. Polychaeta. Danish IngolfExpedition, 4(4): 1-92.

Scient. ed.: D. Martin.

Received July 24, 2006. Accepted February 26, 2007.

Published online May 23, 2007. 